\title{
STUNRERD
}

Descriptions of some new and little known Trematodes of Turtles

Raology

A. M.

1014 




\section{DESCRIPTIONS OF SOME NEW AND LITTLE KNOWN TREMATODES OF TURTLES}

BY

HORACE WESLEY STUNKARD

B, S. Coe College, I 9 I 2

THESIS

Submitted in Partial Fulfillment of the Requirements for the

Degree of

MASTER OF ARTS

IN ZOOLOGY

IN

THE GRADUATE SCHOOL

OF THE

UNIVERSITY OF ILLINOIS

I 9 I 4 



\section{4 \\ Stg}

\section{UN I VERSIT Y OF I L L INOIS}

THE GRADUATE SCHOOL

I HEREBY RECOMMEND THAT THE THESIS PREPARED UNDER MY SUPERVISION BY

\section{HORACE WESLEY STUIKARD}

\section{ENTITLED}

$$
\text { DESCRIPTIONS OF SOME NEW AITD IITTIE KNOWN }
$$

\section{TREMATODES OF TURTIES}

BE ACCEPTED AS FULFILLING THIS PART OF THE REQUIREMENTS FOR THE

DEGREE OF

\section{MASTER OF ARTS}

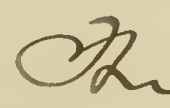

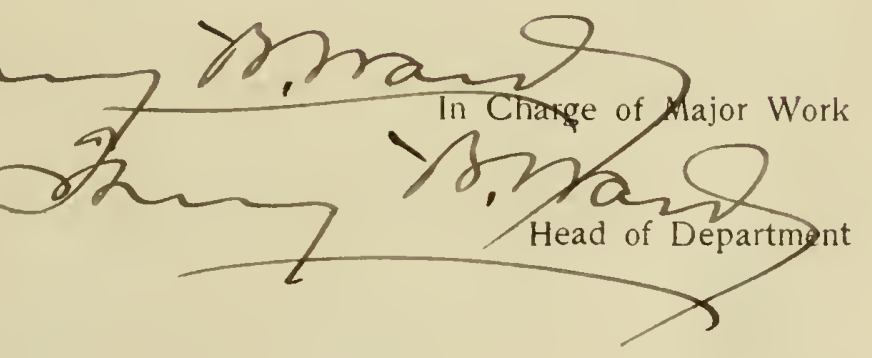

Recommendation concurred in:

\section{Committee}

on

Final Examination 


\section{Digitized by the Internet Archive in 2013}




\section{INTPODUCTION}

While consicerable attention has been paid to the study of the parasites of man and domestic animals, less work has been done on those organisms which infest animals of little economic importance. From a purely scientific point of vier, a knowledere of these forms is essential, since it affords a more complete morphological basis for the determination of relationships and contributes to the solution of taxonomic problems.

During the year 1913-14, I collected parasites of turtles, and the present paper contains descriptions of some of the trematodes found. The material wus obtained from seventy specimens collected from a wide extent of territory. The number of individuals of each species examined, the locality from which they were procured, and the parasites found are listed in the following table. For assistance in wecuring the turtles, erateful acknowledgments are due to Ir. iv.A.Cobb of Tashington, D.C., Professor A. H.orcutt of Denison University, Professor J.E.Ackert of Kansas State Agricultural College, and Professor $\mathrm{W} \cdot \mathrm{E} \cdot$ Burge of the University of Illinois. The work was done under the direction of Professor Henry B. Ward, to whom the author is indebted for inspiration and suggestions. 

Name of INumber Iocality Organ Trematoda turtle examined infected Polystoma

$\begin{array}{cc}\text { P. has- } & \text { P.orbic- } \\ \text { sali } & \text { ulare }\end{array}$

Chrysemys

marginata

$$
"
$$

$\frac{1}{4}$

15

Walker, Ia.

lung

"

Urb:na, Ill. intestine

Chicago,III. lung

Chelydra

serpentina

1 Granville,0. lung

1 Urbana, Ill. none

Chrysemys

elegans

22 Havana, I11. (esophagus

1 ilewton, Tex.

(intertine

"

Pseudemys

troosti

2 Havana, IIl intestine

Halacoclemmys

goographicus

2

Cistudo

carolina

1 Falls Church, Va. none

Aromochelys

carinatus

7 Newton, Tex. Urinary

bladder

1

Chrysemys

concinna

2

intestine

Trionyx

ferox

1

(esophagus

(intestine

2

Malacoclemmys

leseurii

10

" $\quad$ (esophagus

(intestine 

Trematoda (cont'd) Aspidocotylea Distoma Monostoma

C: rhadina n.sp. T.corti n.sp. $1 x 2 x 3 x$

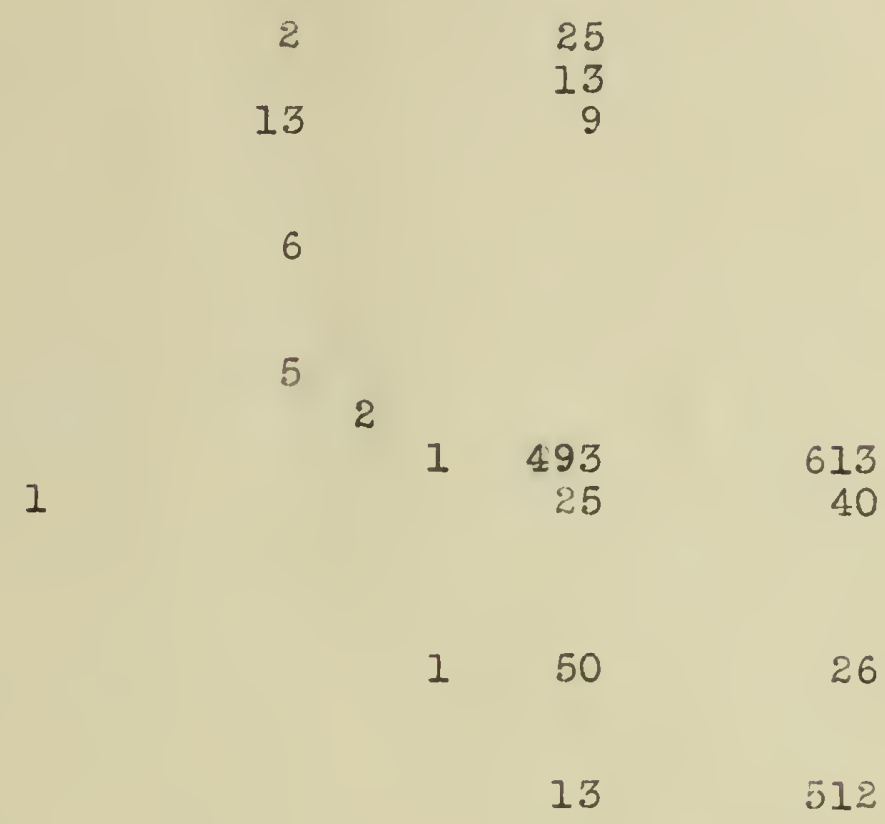

3

5

47

10

1

60

75

13

500 

Methods. The parasites were studied alive, in toto mounts; and in serial sections. For the live study, the worm was placed on a slide in a drop of water or normal saline solution and examined with the low powers of the microscope. The water supports the cover-class sufficiently to permit the animal to move freely. The importance of the live study can not be over-emphasized as it is the best method of tracing the excretory system, and the only way to observe the movements of the animal. The material was fixed in Gilson's, Zenker's, Vom Rath's, Tellyesniczky's, and Kleinenberg's fluids, as well as in a saturated solution of corrosive sublimate to which 2 ? glacial acetic acid had been adced. Sections were cut in transverse, sagittal, and frontal planes from specimens stained in toto in an aqueous solution of Ehrlich's acid haematoxylin, destained in 70\% alcohol, and counterstained with eosir. Balsam mounts were made of toto specimens stained with liayer's haem-alum, Conklin's picro-haematoxylin, Lhrlich's acid haematoxylin, and linyer's paracarmine. Other stains were tried but the results were less satisfactory. 

Cotylaspis rhadina, sp. nov.

In seven of the ten specimens of Malacoclemmys leseurii from Newton, Texas, were found specimens of an undescribed aspidocotylean, the numbers present in each turtle varying from four to twenty five.

Description. The worm (Figs.1,3) is about $1.5 \mathrm{~mm}$ in length by $0.7 \mathrm{~mm}$ in wiàth, anà consists of t:wo distinct parts, an anterior forebody and a posterior, ventral adhesive disc. The forebody has the shape of a cornucopia, the larger end being attached obliquely to the central two-thirds of the dorsal surface of the adhesive disc. Then extended (Fig.l) it manifests an elongate form, projecting beyond the adhesive disc a distance equal to the length of that structure; when in a retracted, compact condition, it may not project beyond the disc. The total length of the worm varies therefore with the state of extension of the forebody, from the length of the aahesive disc to twice that distance.

The adhesive disc is a muscular organ, used for attachment and locomotion. It has a crenulate oval outline, the dorsal surface is arched and the ventral surface is flattened. There is a limiting membrane separating the musculature of the disc from the parenchyma of the body. The ventral surface is divided by two longitudinal and eleven cross ridges into thirty two acetabula, which are arranged in three rows, there being ten median and twenty two peripheral alveoli. These compartments change in shape with the movements of the animal, becoming circular, oval or quadrangular. The size and shape of the disc are relatively constant, a series of measurements of 

twenty mounted toto specimens show that it varies only from 1.2 $\mathrm{mm}$ to $1.4 \mathrm{~mm}$ in length, and from $0.58 \mathrm{~mm}$ to $0.78 \mathrm{~mm}$ in $7 i d t h$. Since in functional capacity and superficial form, this structure recalls the molluscan foot, it has often been termed the foot, altho the morphological comparison is not precise.

Movement consists of extension and retraction of the forebody, which may be turned in any direction, and in the less striking and more restricted movement of the disc. The disc has a tendency to turn up at the edges, especially at the anterior and posterior ends. In adhesion the organ may act as a unit or the different alveoli may function separately. In locomotion there is a reqular series of movements, the forebody is extended and attached by the sucking action of the mouth funnel, then the disc is loosed and the forebody contracted, bringing the anterior part of the disc near the mouth, when the disc is attached and the series of movoments repeated. The worm moves rapidy across the stage of the microscone.

Details of Structure. Externally the worm is coverea by a non-cellular cuticula, which is thichest on the dorsal side of the body, and thinnest on the ventral surface of the adhesive disc. It is without hooks or spines, and on the dorsal side reaches five micra in thickness, while on the disc it is only one micron in thiclness. This cuticula is deflected invard at the external openings. Its outer part is darker colored and appears more dense than that near the dermomuscular wall, altho there is no line of separation. Immediately inside the cuticula is the three layerea aermomuscular wall, the circular, longitudinal and oblique muscles occurring in the order mentioned, the 

circular lying next to the cuticula, and in all parts of the body being better developed than the others. In some places the longitudinal and oblique muscles are very scanty, however those of the ventral side of the forebody are continued caudad in a thin sheet, the so called septum, (Fig.8), which lies just above the limiting membrane of the musculature of the disc and extends posteriad as far as the hinder end of the cirrus sac.

The parenchymous muscles of the forebody are long, often much branched, and nost abundant in locations where they connect different parts of the body wall with each other or with adjacent internal structures. In the anterior part are many well developed muscles, used in the movement of that region. Funning longitudinally among the vitellaria also, there are many muscle fibers. Sphincters and dilators occur at the genital pore, excretory pore and at the opening between the pharynx and intestine. As previously mentioned, the adhesive disc is separated from the forebody by limiting membrane, (Figs.3,4). This membrane runs parallel to the general course of the external, ventral surface, projecting ventrad at each ridge. Extencing betreen the membrane and the ventral wall, there are vertical muscles, often branched, especially at the ends. The ventral projection of the limiting membrane into the ridges of the disc form two sides of long tricngular prisms, which extend longitudinally and transversely above the musculature of the disc. One face of this prism is dorsal and the opposite angle extends ventrad, increasing the size an prominence of the ridges which separate the aisc into fossettes. 

The Alimentary Tract. The mouth funnel (Fig.10) is a cup shaped muscular structure, which functions as an organ of attachment, there being no oral sucker. It is $0.08 \mathrm{~mm}$ to $0.1 \mathrm{~mm}$ in diameter, sub-terminal in position. There is no prepharynx, the mouth funnel opening directly into the lumen of the pharynx. The latter is a spherical muscular orgen $0.09 \mathrm{~mm}$ to $0.1 \mathrm{~mm}$ in diameter. It is followed by a short esophagus, an anterior section of the digestive tube, differing only in that it is lined with flattened epithelial cells. The intestine is of the rhabdocoele type, extending on the dorsal side of the boay 0.1 to $0.2 \mathrm{~mm}$ posterior to the hinder end of the testis. It varies but slightly in caliber, averaging about $0.075 \mathrm{~mm}$ in diameter. The wall consists of two layers, a muscular layer comsosed of outer longitudinal and inner circular fibers, and inside this a single layer of large epithelial colls. A portion of the wall of the intestine is show in Fig. 9, and represents the large deeply staining nuclei of the epithelial cells lying in the proximal, basal part of the cell, while many delicate, elongate processes extend out into the lumen of the canal.

The Excretory System. (Fig.4) Most of the observations on this system were made on the living animal. As the vater evaporated from the mount, the worm was flattened, and the larger excretory tubules could be easily followed. The pore is dorsal, at the posterior end of the forebody. There is a single excretory vesicle, which is situated betteen the large flask lize ends of the collecting ducts and the pore. In the pulsations of this organ, the anterior part contracted and the constriction passed 

posteriad, expelling the fluid thru the pore. Two collecting ducts extend cephalad from the excretory vesicle, one on either side of the forebody, median to the vitellaria. Just posterior to the pharynx, each vessel divides, sending a brach cephalad on either side of the digestive tube, and a median branch which turns caudad, sub-dividing into a branch extending to the region of the genital pore, and a larger, longer branch which pases posteriorly to the region of the testis and $\bigwedge$ smaller side branches. Cross sections show the collecting ducts to be dorsal in position, but the smaller tubes do not show in sections.

Female Reproductive Organs. The ovary (Figs.5,7) is a small organ, triangularly ovoid in shape, $0.16 \mathrm{~mm}$ in lenth by $0.1 \mathrm{~mm}$ in width, and $0.5 \mathrm{~mm}$ in thickness. It is located at the right of the median line, about midway betreen the cephalic and caudal ends of the forebody. In vell extended specimens, it is nearer the posterior end, and in much contracted ones nearer the anterior end. Cells in various stages of mitotic division were observed in sections. The duct arises at the posterior, lateral margin of the ovary and passes posteriorly, receiving a common vitelline duct, ana then expanding into several enlarements. It continues posteriorly on the lateral side of the collecting auct of the excretory system, as far as the hinder part of the testis, where it turns to the median line. Here it passes ventrally and anteriorly beneath the testis; in front of the testis it turns dorsad and toward the ovary, but just before reaching the ovary it turns squarely across to the opposite side of the body and passes with little deviation airectly to the pore. Eggs with shells were found as far from the pore as the region below the 

testis, and when the worms were placed in tap water, the eggs near the pore were extruded. The eggs are few in number, not more than six were found in any one specimen. In size they ranged from $0.071 \mathrm{~mm}$ to $0.086 \mathrm{~mm}$ in wioth and from $0.137 \mathrm{~mm}$ to $0.145 \mathrm{~mm}$ length. The average of twenty five eggs measured was $0.141 \mathrm{~mm}$ in length by $0.075 \mathrm{~mm}$ in width. The vitellaria (Figs.1,3) are arranged along the sides of the forebody, extending from the posterior end to the cirrus sac. They are more numerous and closer together in the hinder region, gradually becoming fever in the anterior part of the vitelline zone. They lie just above the limiting membrane which forms the dorsal boundry of the musculature of the adhesive disc, and number un to forty on each side. In size they vary from small follicles $0.01 \mathrm{~mm}$ in diameter to lobes 0.03 or $0.04 \mathrm{~mm}$ in diameter.

Male Reproductive Organs. The testis (Figs.1,3,9) is a large, single, median organlsituated $0.25 \mathrm{~mm}$ to $0.35 \mathrm{~mm}$ from the posterior end of the forebody, and in the anterior third of the posterior half of the region of the adhesive disc. It is almost spherical and measures from 0.25 to $0.35 \mathrm{~mm}$ in diameter. Cells in all stages of division and mature spermatozoa are to be seen in sections. The sperm duct arises at the anterior, ventral part of the testis and turns to the left, entering the side of a long, much coiled seminal vesicle. The seminal vesicle is a large tube, $0.1 \mathrm{~mm}$ to $0.175 \mathrm{~mm}$ in diameter, extending from the testis to the cirrus sac. It is coiled eight to sixteen times and filled with masses of spermatozoa. Ilear the pore it enters a large muscular walled cirrus sac, $0.2 \mathrm{~mm}$ long and $0.145 \mathrm{~mm}$ wide, which is filled with large unicellular, prostate glanàs. These gland cels are 

pyriform, measuring on the average $0.026 \mathrm{~mm}$ long by $0.017 \mathrm{~mm}$ in wioth. Inside the cirrus sac there is a ailated curved portion of the duct, which has muscular walls and is lined with large nucleated epithelial cells, (Figs.7,8). The cirrus was observed in the extruded condition.

The common genital pore (Fig.ll) is in the median line, on the ventral side of the forebody, above the point of attachment of the adhesive disc. The opening of the cirrus is on the right side while the metraterm onens on the left.

Sensory structures. There is a dorsal nerve commissure crossing the anterior part of the pharynx, and lateral nerves were traced running cephalad and caudad from it. In about one third of the specimens, a pair of black eye spots wre present on the dorsal commissure, situated just dorsad of the lateral wals of the pharynx.

At the ends of the cross partitions of the adhesive disc are the "Marginal Organs", (Randiurper, Iooss). These structures (Figs.2,8) occur in the angles where the transverse ridges meet the musculature of the margin of the disc. Ieading to the exterior, there is a narrow canal, which is surrounded by strong muscles, and above this a large circular cavity, which was empty in the specimens sectioned. In the study of the living animals, these organs were everted and retracted as the animal moved. They were moved rapidy and when extended loored like membraneous sacs. The rapid, connected and accurate movement would suggest a good nerve supply, altho nerve fibers were not demonstrated. Most workers regard them as sensory, while many believe them to be glandular as well. 

Comparisons. This is the third aspidocotylean described from turtles, the tiro previously reported forms being cotylaspis lenoiri Poirier (1880), and Iophotaspis vallei Stossich (1899), both African forms. Poirier described $c$. lenoiri from the intestine of Tetrathyra vaillanti of Senegal, and Looss(1902)reports it as occurring also in Prionyx notilica of the Nile. Lophotaspis vallei lives in the stomach of Thalassochelys corticata, a turtle of Egypt. The species describes in this paper is very different from Iophotaspis, but shows considerable resemblance to C. lenoiri and exact agreement with the generic description as given by Leidy for Cotylespis, at once places it in that genus. The characters of the genus Cotylaspis as oiven by Leidy (1858) are "Body curved infundibuliform, anteriorly cylindro-conical, posteriorly expanding into a subcircular or oval ventral disc with numerous acetabula arranged in a trinle series. liouth infero-terminal, with prominent upper lip, and protractile into a cup or disc like acetabulum. Intestinal apparatus as in Aspidogaster, eyes two, distinct, black, situated on either side of the head. Generative apertures inferior,between the head and ventral disc."

Leidy's type species, insignis, is described by him as "Translucent white or pink white, upper lip snout like, conical, ventral disc crenate at the margin;acetabula 29, oblong quadrate, the outer rows continuous in front and behina forming a circle. Length one half to one line, ventral disc one fourth to one half line. Adheres to the outer surface of the renal organ and upper margin of the foot, within the cleft of the upper branchis cavity of Anadonta fluviatilis and A. lacustris." Further information 

is contributed by Osborn (1904) from specimens collected at Iake Chautauna, $\mathbb{N} \cdot Y \cdot$, parasitic in various species of Anadonta, and in two cases in Unio Iuteolus. However Osborn's description does not contain complete measurements, and since there are no other descriptions, many of the following comparison's are drawn from his figures. A tabulated comparison of the species of Cotylaspis shows their specific distinctions.

Characters

length

width

ventral disc

acetabula

marginal

organs

pharynx

no size given

$0.1-0.3 \mathrm{mmlong}$

$0.07-0.13$ mriwi de

eg.gs

$0.82-0.35 \mathrm{~mm}$ long

$0.1--0.16 \mathrm{~mm}$ wide

testis

$0.18-0.26 \mathrm{~mm}$

cirrus sac
C. Ienoiri (Leidy, 1.5-3.0m

(Osborn, $1.2-1.8 \mathrm{~mm}$

$0.6-1 \mathrm{~mm}$

$1.7 \mathrm{~mm}$

$1 \mathrm{~mm}$

circular

c. rhadina

broadly oval

7 median, 18 peripheral

10 median,

$1 \cdot 2--3 \cdot m^{m}$

$0.58-0.78 \mathrm{~mm}$$$
18 \text { peripheral }
$$

\begin{tabular}{|c|c|c|c|}
\hline ovary & $\begin{array}{l}0.1-0.3 \mathrm{rm} l \text { ong } \\
0.07-0.13 \text { mawi de }\end{array}$ & $\begin{array}{l}0.22 \mathrm{mml} \text { ong } \\
0.10 \mathrm{~mm} \text { ide }\end{array}$ & $\begin{array}{l}0.69 \mathrm{~mm} \text { long } \\
0.16 \mathrm{~mm} \text { wide }\end{array}$ \\
\hline eggs & $\begin{array}{l}0.2-0.35 \mathrm{~mm} \text { long } \\
0.1--0.16 \mathrm{~mm} \text { wide }\end{array}$ & $\begin{array}{l}0.43 \mathrm{~mm} \text { long } \\
0.14 \mathrm{~mm} \text { wide }\end{array}$ & $\begin{array}{l}0.13-0.14 \mathrm{~mm} \text { long } \\
0.07-0.08 \mathrm{~mm} \text { wide }\end{array}$ \\
\hline testis & $0.18-0.26 \mathrm{~mm}$ & $?$ & $0.25-0.35 \mathrm{~mm}$ \\
\hline cirrus sac & about size of ovary & ? & 0.2 by $0.145 \mathrm{~mm}$ \\
\hline
\end{tabular}

The above comparison shows decided differences in the size and shape of the worms, the size and shape of the disc, number of alveoli and marginal organs, size of ovary and testis, as well as size of the cirrus sac and eggs. 

Classification. Revisions or summaries of the

Aspidocotylea have been made by Diesing (1859), Taschenberg (1879), Hoyle (1888), Ironticelli(1892), Braun (1889-93), and Nickerson (1902). Present information seems to support the validity of the following genera.

\section{Aspidogaster von Baer 1827 .}

Type species, A. conchicola von 3aer 1827.

Oval adhesive disc, four rows of alveoli, marginal organs present, mouth subterminal, no oral sucker, one testis. This genus contains A.conchicola, which infests the kidney and pericardium of various species of Unionidae in Europe and liorth America. It also is found in gasteropods and in the immature condition in the intestine of Unionidae. The other species included in this genus is A. limacoides, a form which stafford (1896) and Kofoid (1899) suspect of being identical with $A$. conchicola. A. Iimacoides occurs in the intestine of different species of leuciscus in Europe. Another species, macdonaldi, was placed in this genus by lionticelli (1892) and removed to Lophotaspis by Looss $(190 \%)$.

II. Cotylaspis Leidy 1857.

Type species, C. insignis Leidy 1857. oval adhesive disc, three rows of alveoli, mrinal organs present, mouth subterminal, no oral sucker, one testis. This genus contains C. instgnis, C. lenoiri, and C. rhadina, n.sp. A description of $C$. insignis has been given. C. Ienoiri was described by loirier(1886) as a species of Aspidogaster. Monticelli (1892) created a new genus, Platyaspis, to 

contain Poirier's species, evidently overlooking the the similarity between it and the form reported by Leidy. He declined to accept the genus cotylaspis, suggesting that insignis was a species of Aspidogaster. Braun (1889-93) ascribes the species insignis to Aspidogaster. Kofoic (1899) established the validity of Leidy's genus, but contended that genus Platyaspis should be retained for Poirier's species; first because of the difference in the number of alveoli, insignis having 29 and lenoiri 25; second, Cotylaspis has eyes while poirier did report such structures for lenoiri; and lastly, because of the difference in habit, insignis being an ectoparasite, while lenoiri occurs in the intestine. Nickerson argues that these cifferences are not of generic importance. To substantiate his position he states that the number of alveoli is variable in every genus in the family, and often in the same species. Both insignis and lenoiri have three longitudinal rows of alveoli and the number of fossettes varies with the number of transverse riages, which latter increase in some forms with the age of the animal. Developmental differences in the number of alveoli are reported for cotylaspis by osborn, Macraspis by Jugerskiblā, Stichocotyle by Odhner, and Aspidogaster by stafford. In regard to the presence or absence of eyes, Hickerson recalls that not all specimens of insignis have eyes, and that Poirier's silence on the subject does not necessarily imply that such structures are absent in lenoiri. Nickerson continues the aroument by saying that the presence or absence of eyes is of no more importance than the presence or absence of marginal organs, which structures are not mentioned by Poirier. Concerning the ectoparasitic habit of one and the endoparasitic habit of the 

other, he says that habit is really of less importance than habitat, and more significance might be attached to the fact that one is an African and the other a North American form. Morphologically Poirier's species is similar to Cotylaspis and the evidence appears sufficient to justify the suppression of lionticelli's genus Platyaspis and Aspidogaster lenoiri, Poirier 1880, Platyaspis lenoiri (Poir.'86) Monticelli 1892, become synonomous with Cotylaspis lenoiri Poirier 1886.

Cotylaspis then contains the species, insignis Leidy 1857, a ectoparasite occurring in the mantle cavity of Unionidae in Forth America.

lenoiri Poirier 1886, from the intestine of the turtle Tetrathyra vaillanti of senegal.

rhaina n. sp., from the intestine of lialacoclemmys leseurii of North America.

III. Macraspis OIsson 1868.

Type species, $\pi \cdot$ elegans Olsson 1868.

This genus has a single row of confluent acetabula in the adhesive organ, sense organs present, mouth terminal, one testis. The single species is parasitic in the rall bladder of Chimaera monstrosa, a fish from the coast of Europe.

IV. Stichocotyle Cunningham 1884

Type species, S. nephropis Cunningham 1884.

There is a single row of more or less distinct acetabula, sense organs lacining, mouth subterminal, oral sucker absent, two testes.

Cunningham's original description was of the l=rva ana 

Monticelli (1893) declined to recopnize its generic importance, thinking it might be an immature form of Macraspis. Odhner (1898) however, by discovering the acult and tracing the life history, established the genus. Acults live in the bile ducts of the liver of rays: larvae occur encysted in the vall of the intestine of the larger marine Crustacea. Cunningham described it from the Horwogian lobster, Nephrons, and iickerson (1895) reports it from the American lobster, Homarus americanus.

V. Cotylogaster honticelli $18 \div 2$.

Type upecies, C. michaelis lonticelli 1892.

Adheive disc with three rows of alveoli; sense organs present, mouth terminal; oral sucker present; tivo testes.

There are two species.

c. michaelis occurs in the intestine of Cantharus vulgaris, a European fish.

c. occidentalis ivicrerson 1899, occurs in the intestine of Aplodinotus grunniens of irorth America.

VI. Lophotaspis Looss 1902.

Type species, I. vallei (stossich) 1899.

Achesive organ with three rows of alveoli; eversible sense organs present at all the intersections of the ridges of the the adhesive dis; cirrus absent.

Looss (1901) reported Iophotaspis adhaerens as a worm belonging to new senus of the wpidobothriane, hut nas not aware that stossich (1899) had described the same form as Aspicogaster vallei. Looss (190:) described and figured the form as Iophotaspis vallei.

In the same paper(1902) Iooss compared Aspidogaster 

macdonaldi with Lophotaspis and placed it in that genus. This tremotoce was reported by lacionala(1878) but not namea by him, and Monticelli (1892) named the forn as a species of Aspidogaster. Nickerson (1902) declared it to be an aspiaobothrid, but different from all other known aspidobothrids, and predicted that a new genus rould have to be created for it when its structure is better known. líacdonala reported 180 extensile structures, like tentacles of a snail, occurring at the margins and intersections of the ridges of the adhesive disc. Nothing is known of the internal structure. Looss in placing the worm in the genus Lophotaspis states "lit ihrer tentakeltragenden Bauchschiebe bildet die Art aber ganz zweifellos einen fremen Eindringling in dor Gattung Aspidogaster, da dessen typischen $\Lambda$ t jedenfalls solche Tentakel nicht besitzt. Gerade diesen auffallenden Character aber tielt sie mit Iophotaspis: ich bin geneigt, A. macdonaldi Monticelli, trotsdem wir von seiner inner Organization noch nichts wissen und trotsdem bei ihm die Genitaldffnung weiter Ruckwarts liegt als bei Lophotaspis vallei, aus dem Genus Aspidogaster herauszunehmen und zu Jophotaspis zu stellen". This form certainly does not belong in the genus Aspidogaster, and until its internal structure is known, it may well be placed with Iophotaspis.

I agree with Jdgerskidld that it is much too early to undertake a final systematis revision of the Aspidobothricae. The discovery of the sexual form of stichocotyle by odhner (1898) establishes the fact that at least one species of the Aspidocotylea has an intermediate host, and the family is thus both monoen tic and digenetic. Nickerson observes "owing to the well known tendency of fresh water conditions to obliterate larval life, it may 

well be that Aspidogester has secondarily lost a more or less complicated series of changes, which have been retained by its relatives inhabiting salt water". The presence of both monogenetic and digenetic development within the family, together with other characters common to both the Heterocotylea, and Malacocotylea designate it as an intermediate group. The morphological structure is like that of the aigenetic trematodes, but whether or not the Aspidocotylea are primitive or secondarily degenerate forms is as yet undeciôed. 

Polys toma orbiculare, sp. nov.

Two nolystomes were obtained from the esophagus of a single specimen of Trionyx ferox, from Newton, Texas, and another similar worm was found in the esophagus of lialacoclemmys leseurii, from the same region. These trematodes were very small, the same color as the lining of the esophagus, and so firmly attached that they were removed only with great difficulty.

The worms (Fig.12) measured $4,3.75$, and $3.25 \mathrm{~mm}$ in length by $1,0.85$, and $0.8 \mathrm{~mm}$ in width at the widest part. The body is oval, flattened dorso-ventrally, altho the shape varies greatly, depending on the state of contraction of the animal. In an extended condition it narrows at either or both ends, and the contracted form may be broady oval to quaarate. On the ventral side, at the posterior end of the body is an achesive disc, carrying six acetabula, which are arranged compactly in a circle. The disc is slightly wider than the greatest width of the body, being $1.09 \mathrm{~mm}$ to $1.21 \mathrm{~mm}$ in width, while each bothrium measures about $0.4 \mathrm{~mm}$ in diameter.

The cuticular covering of the body is $0.014 \mathrm{~mm}$ in. thickness, and is usually because of the contraction of the body. thrown into minute folds and furrows. Externally the cuticula is dotted with very small chitinous granules.

The anterior sucker is an oval structure measuring 0.2 to $0.22 \mathrm{~mm}$ in length by $0.2775 \mathrm{~mm}$ in width. It is merely a mouth funnel, which functions as an adhesive organ, there being no oral sucker. At the base of this anterior sucker is the pharynx (Fig.14), a spherical muscular structure $0.3 \mathrm{~mm}$ in diameter. There is a broad dorsal nerve commissure crossing the anterior 

part of the pharynx, which contains large ganglion cells (Fig. 15). The dorsal commissure is continuous with a nerve ring that passes ventrad on either side of the pharynx.

The digestive tract is of the triclad type, the pharynx is followed by a short esophagus, $0.17 \mathrm{~mm}$ in length and the diverticula of the intestine extend as simple tubes to the posterior end of the body, being approximately $0.15 \mathrm{~mm}$ in diameter, and ending blindly just dorsal to the middle pair of bothria. The caeca are lateral in position, but are quite close together, being only about 0.2 to $0.25 \mathrm{~mm}$ apart. They have the usual muscular coat and epithelial lining, and were empty in the specimen that was sectioned.

\section{Reproductive Organs. (Fig.20) The testis (Eig.16) is} a large spherical organ, 0.4 to $0.5 \mathrm{~mm}$ in diameter, situated in the median line of the body. It is in the posterior part of the cephalic half of the rorm, and is composed of a large number of small lobes, compact and contained in a membraneous capsule. Cells in all stages of mitotic division and mature spermatozoa were observed in sections, the spermatozoa measuring approximately $0.014 \mathrm{~mm}$ in length. Two tubes, one from either side, arise from the anterior ventral region of the testis and unite to form the sperm duct, which curves dorsad, then after passing cephalad, it turns ventrad into the cirrus sac which opens to the surface at the common genital pore. The ovary is a comma shaped organ, located on the left side of the body. In dorsal view it is from 0.16 to $0.2 \mathrm{~mm}$ in length, and 0.08 to $0.12 \mathrm{~mm}$ in width, while in the specimen that was sectioned it is $0.08 \mathrm{~mm}$ in width and $0.3 \mathrm{~mm}$ 

in thickness. The oviduct arises at the posterior point of the ovary, and after receiving a short duct from the vitello-vaginal canal, it coils dorsally and anteriorly, passing thru a small shell gland and crossing to the opposite side of the body, where it expanos into a large uterus. There are tiro vaginae, one opening to the surface on either side, at the ventral, lateral margin of the body, just opposite to the posterior part of the ovary. Near the external opening each vasina receives a duct from the common vitelline canal, and the vaginae meet in the median line of the body, where a short tube connects with the oviduct. The vacinae thus form a tube, leading thru the body from one side to the other. In each of the specimens, there was a single large egg in the uterus, and in the one sectioned the uterus extended cephalad of the pore and to a point only $0.03 \mathrm{~mm}$ from the bifurcation of the intestine. The eggs are broacily oval, $0.25 \mathrm{~mm}$ long by $0.2 \mathrm{~mm}$ wide. They are very refractive to light, do not stain, and in sections the egg looks like a mass of homogeneous jellow yolk.

The uterus and cirrus sac open into the cloaca, the opening of the cirrus is anterior and at the left of that of the uterus. The common genital pore is situated in the median linefof the body about $0.12 \mathrm{~mm}$ caudad of the bifurcation of the intestine, and is surrounded by a coronet of spines, there being 32 in one mounted specimen and 33 in the other. These cirrus spines or hooks (Fig.18) are sickle shaped, and have branched processes which are embedded in the musculature of the walls and in entire length they messure $0.05 \mathrm{~mm}$, the hook proper comprising a little over half the total length. 

The vitellaria are large compact follicles underlying the entire dorsal surface of the body, except the region over the uterus and pharynx. Common collecting ducts run longitudinally along the body, lateral to the intestinal diverticula, and these open on either side to the vaginae.

Armatur of the Adhesive Disc. Each bothrium has a chitinous skeletal structure, (Figs.12,17), cup or bell shaped, on the inside walls of which there are 32 parallel cuticular ridges, extending to the exterior. Betreen the anterior pair of bothria, the chitinous granules which dot the cuticula of the body have been developed into many minute spines. In one of the mounted specimens two of the spines were larger than the others and possessed hooked points; they were $0.007 \mathrm{~mm}$ in length. There is no regularity in the arrangement or characteristic size for the spines. Between the posteior pair of bothria, there are tro large chitinous rods, i.e. without sharp hooked tips, $0.075 \mathrm{~mm}$ in length, and between these a smaller pair, $0.046 \mathrm{~mm}$ in length. Near the posterior margin of the disc in one specimen, there was one well developed hook, and in the other three small chitinous spines. In the base of each bothrium there is a small hook $0.009 \mathrm{~mm}$ in length (Fig.19). 

Comparisons. Of the described polystomes, two species, $P$. integerrimum and $P$. uncinatum are parasitic in the urinary bladder of Iuropean frogs. The other European form P.ocellatum occurs in the pharyngeal cavity of Emys europa and Halichelys atra. The three previously known American forms are all from turtles, P. oblongum occurring in the urinary bladder of Aromochelys odoratus, P.coronatum in the fauces of Chrysemys rugosa, and P.hassali in the urinary bladder of Kinosternum pennsylvanicum. In size and external characters, P. orbiculare agrees closely with Leidy's description of P.coronatum.

A comparison of . . orbiculare with one of the type specimens of P.coronatum, however, shows undoubted specific differences in the number and arrangement of the vitellaria, the size and shape of the adhesive disc, and the number and arrangement of the hooks which occur on the disc. The vitelline lobes of $P$. orbiculare are larger, more numerous and more compact, and the differences in the ahesive disc are shown in a tabulated comparİson.

Characters

Shape of disc

Wiath at anterior bothria

width at the midde bothria

Width at posterior bothria

Gential hooks

Hools between

anterior bothria
P.coronatum

cordiform

$1.24 \mathrm{~mm}$

$1.18 \mathrm{~mm}$

$0.78 \mathrm{~mm}$

$32, \quad 0.037 \mathrm{~mm}$ long distal ends bifid.

6, $0.023 \mathrm{~mm}$ 1ong:
P.orbiculare

circular

$0.68 \mathrm{~mm}$

$1.04 \mathrm{~mm}$

$0.72 \mathrm{~mm}$

32, $0.05 \mathrm{~mm}$ long distal ends hooked. 

Hooks between

$\begin{array}{lll}\text { posterior bothria } & 3 \text { pairs } & 2 \text { pairs of rods } \\ \text { Largest pair } & 0.143 \mathrm{~mm} \text { long } & 0.075 \mathrm{~mm} \text { long } \\ \text { median pair } & 0.074 " \mathrm{n} & 0.046 " ~ \\ \text { posterior pair } & 0.023 " ~ & \end{array}$

The shape and armature of the posterior disc of $\mathrm{P}$. coronatum are similar to those features in all previously figured polystones, ,P.integorrimum, P. oblongum, and P.hassali, but the shape of the adhesive disc and character of the armature of the Texas specimens is very different. Fig.l7 shows the close proximity of the anterior bothria, and the difference in shape, together with the departure from the usual arrangement of hooks at once mark the Texas worms as belonging to a new species. Because of the shape of the adhesive disc, the name orbiculare is proposed for this new form.

The simple triclad digestive tract and the reproductive organs as described for $P$. orbiculare are similar to the corresponding structures in all other polystomes, with the exception of the endoparasitic form of P.integerrimum. The single egg in the uterus is common for all American forms of this genus whose anatomy is known. There are no prominent "Seitenitlste" at the external openings of the vaginae, such as are described for $P$. integerrimum, but beneath the surface of the body at these points are spongy masses which may correspond to those structures. The vitellaria are more numerous than in any described American form, and in this respect correspond only to $P$. ocellatum. 

Polystoma hassali Goto, 1899

A single polystome (Fig.21) was found in the washings of the intestine and urinary bladder of Aromochelys carinatus from Newton, Texas. Unfortunately these organs vere examined in the same dish, and the present specimen, which ras found in the washings, may be from either, but since Goto described the form frum the urinary bladaer, it is probable that the present specimen is from that organ. Upon staining and mounting the specimen it proved to be P.hassali, a species that Goto (1899) described from the urinary bladder of Kinosternur pennsylvanicur from Maryland. The worm is $1.35 \mathrm{~mm}$ in length, with an adhesive aisc the same size and shape as that described for P.hassali. It is armed in the same manner as that figured by Goto. However he revorts the smaller hooks that occur in the bases of the bothria and at the anterior and posterior margins of the disc as being $0.33 \mathrm{~mm}$ in length, and the larger holrs with bifid bases, and that are between the posterior bothria as being $0.125 \mathrm{~mm}$ in length. This is evidently an error, since he figures the posterior hooks as about four times the size of the smaller ones. In the present specimen, the larger hooks are $1.25 \mathrm{~mm}$ in length and the smaller ones 0.033 , which figure agrees with that of Goto by a change of one place in the decimal point. Goto makes no mention of the number or size of eggs. The Texas specimen has a single large egg in the uterus, the usual condition for polystomes. The egg is badly collapsed but measures $0.255 \mathrm{~nm}$ by $0.11 \mathrm{~mm}$. 

The genus Polystoma Zeder 1800, is described by Braun (1890). "Body long egg shaped, anteriorly tapering to a point, posteriorly extending as a broad adhesive disc, upon which are two longitudinal rows of outaard springing bothria. Between those at the posterior end are large chitinous hooks. The vagima is double opening at the right and left sides of the body; eggs oval, without filaments. occurs on the gills and in the urinary bladder of Amphibia and in the esophagus of turtles".

The genus contains seven snecies, among which p.integerrimum is the most common and beet knorn species. The adults occur in the gill chamber and urinary bladier of frogs and toads in Europe; larvae occur on the gills of tadpoles and migrate to the urinary bladder when metamornhosis takes place. Zeller (1876) showed that if sexual maturity is attained on the gills of the tadpole, the structure of the worm resulting is very different from that of the adult which matures in the urinary bladder. The form found in the urinary bladder has a lobulated testis, two vaginae, many eggs in a long coiled uterus, and a much branched intestire, while the ectoparasitic form has a single testis, no vaginae, single egg in the uterus, and a simple triclad intestine. P. integerrimum is about $12 \mathrm{~mm}$ long, with the surface cross wrinkled. There are eight spines in the coronet surrounding the common genital pore.

P.ocellatum Rudolphi 1819 is parasitic in the esophagus of Emys europa, Cistudo europa, and Falichelys atra, all European species. It is flesh red in color and from 3 to $5 \mathrm{~mm}$ in length. Eyes are present in young animals but later disappear. The pharynx is pyriform and there is a simple forked intestine. The testi 

is a lobea structure; the ovary is a large quadrate organ, in ibout the midale of the body. The large lobed jolk glands are dorsal and fill the region from the mouth sucker to the posterior disc. Their ducts unite to form a common duct which opens into the oviduct. A shell gland and ootype are present. The uterus opens at the posterior part of the genital pore. There is no internal vas deferens. The genital pore is in the median ventral line of the body, posterior to the acetabulum, and is surrounded by a circle of about 40 hooks. the vaginae are anterior, about one third of the length of the body from the cephalic end.

P.oblongum Wright 1879, was described from four specimens obtained in the urinary bladder of the musk turtle. Aromochelys odoratus of Canada. Stafford (1902) also reports it from Chelydra serpentins in the^locality. "The body is oblong, the mouth being on the ventral surface of the rounded anterior end. The piarynx is bowl shaped, The intestinal caeca without branchings, cirrus coronet composed of 16 alternately large and small hooks, which are sabre sheped. Iength up to $2.5 \mathrm{~mm}$; breadth $1.5 \mathrm{~mm}$. Viviparous. Egg greenish, $0.235 \mathrm{~mm}$ by $0.195 \mathrm{~mm}$. The larva is ocellate, $0.5 \mathrm{~mm}$ in length. The testis is a solid structure in the posterior third of the body. Vitellaria scattered, but not numerous; hooks as in P.integerrimum."

The single specimon reported by Ieidy from the urinary bladder of Pseudemys rugosa of liaryland, and assigned by him to the species oblongum Wright, has been examined by Goto (1899) and his observations show that it is not P.oblongum. It had 16 cirrus spines, all the same size and shape, mesuring $0 . j 6 \mathrm{~mm}$ in length. 

Each spine consists of ${ }^{\prime}$ portions, a distal awl shaped part with an expanded base, and handle like part, consisting of tro slender filaments; In oblongum Iright, the spines are alternately large and small, hence Leidy's specimen is not oblongum iright, but must be a new species. The naterial "ras in such poor condition, however Goto did not attempt a description and for the present it remains unknown.

P.uncinatum Mace 1880, is about $5 \mathrm{~mm}$ long and was reported from the gall bladder of Rana temporaria from France.

P.coronatum Leidy 1888, was described from four specimens of Pseudemys rugosa, three from the throat and one from the nasal cavity. Leidy's original description is, "Body when elongated lancelate; caudal disc vider than the hody, coraiform, three pairs of bothria, the body being attached between the anterior two pairs; changeable in form to oblong, circular or quadrate; with three pairs of minute hooks between the anterior pair of bothria, and one larger and t:yo smaller pairs of hooks between the last pair of bothria, genit l aperture jith circular or transverse ovel coronet of 32 hooks of equal length. No eyes visible. Iength elongated 4-6 min, contracting to one half that length and widening proportionately

P.hassali Goto 1899, ws described from the urinary blader of Kinosternum pennsylvanicum from liaryland. Total length of body $1.5 \mathrm{~mm}$; body ovate; adhesive disc hexagonal; suckers at the angles, each with a minute hook in the center; Three pairs of hooks between the anterior pair of suckers; three ruirs between the posterior bothria, a large pair, $0.125 \mathrm{~mm}$ long, bifia at tre 

base, and two smaller pairs, the same size and shape as those that occur in the suckers, possessing lateral processes and measuring $0.033 \mathrm{~mm}$ in length. There is a bifurcated, unbranched intestine. The genital coronet contains $15-16$ spines, $0.028 \mathrm{~mm}$ in length, straight with wing like processes in the midale. The testis is a large ovoid organ, with a lobulated margin, and situated in the posterior half of the body. The ovary is comma shaped, anterior to the testis, on either the right or left siae; the oviduct proceeds obliquely forward, and expanding into the uterus, which is just posterior to the genital pore. The veginal openings are Iateral, without papillae, midway between the cephalic and caudal ends of the body proper, the two varinal canals directed almost straight across the body and meeting in the median line. Genitointestinal canal slightly behind the vagina on the same side of the body as the ovary. Vitelline lobes not very numerous, separated from one another, mostly confined to the lateral portion of the body, but present in the median portion behind the testis. 

Telorchis corti, sp. nov.

In the intestine of seven of the ten specimens of

Malacoclemys leseurii from Newton, Texas, there were found some fifty distomes, most of them immature worms; and another adult of the same kind was obtained from the intestine of a single individual of Chrysems elegans from the same region.

These worms proved to be of a single species and later were found to identical with others Dr. H.J.Vancleave had collected in June 1910 at Havana, IIl. from the intestine of Malacoclenmys geographicus. Dr. "W.Cort, to whom this latter material had been given, turned it over to me, together with specimens of Telorchis aculeatus and T.robustus, and in appreciation of his kindness, the worms which proved to be a new species, I shall name Telorchis corti.

The largest specimens (Fig24) measured $7.15 \mathrm{~mm}$ in length, by $0.5 \mathrm{~mm}$ in width at the widest part, and the smallest sexually mature forms i.e. those with eggs in the uterus, were about 4 mm long and 0.35 mide at the widest part. In the acilt the greatest widh is at the region of the acetabulum, the worm tapering slightly toward either end, being narrower at the caual end of the body. In immature specimens the section of greatest widh is further anter10x, being in the pharyngeal region. The worm is Plattened dorsoventrally, being thickest at the median line and becoming thinner toward the lateral edges

The boày is covered by a heavy cuticula, 0.004 to 0.008 mm in thickness, and in the living worms it was armed with a covering of minute spines arranged in rows. These spines were 

lost in the rrocess of technique, and do not show in the mounted specinens. A few were found in sections and measured $0.014 \mathrm{~mm}$ in length.

The acetabulum is in the median line, one sixth to one seventh of the length of the booy from the anterior end. It is circular, $0.14 \mathrm{~mm}$ in diameter. The oral sucker is sub-terminal in position and measures $0.14 \mathrm{~mm}$ in diameter, being the same size and shape as the oral sucker. Here as in all distomes, there is a true oral sucker and not a mere sucking mouth funnel such as occurs in the Aspidocotylea.

The oral sucker is followed by the pharynx, a spherical muscular structure 0.07 to $0.08 \mathrm{~mm}$ in diameter. The esophagus is a short tube, $0.05 \mathrm{~mm}$ long and $0.025 \mathrm{~mm}$ in diameter, leading from the pharynx to the diverticula of the intestine. The esophagus is longer proportionately in immature worms than in the aciult condition. The intestine is bifurcate, the diverticula meeting anteriorly at an acute angle, and extending to the posterior end of the body. There are only slight variations in caliber, and these are probably due to pressure from the genital organs, or the contraction of the musculature of the body. On either side of the body the branches of the intestine lie between the uterus and the vitellaria, forming lines of separation between these organs. The wall of the intestine is composed of scant longitudinal and circular fibers, while the lumen is lined with the usual digestive epithelium. The caeca wore empty with the exception of a f'e if partly decomposed fragments. 

Reproductive Organs. (Figs.22,24) The ovary is a broady oval structure, slightly left of the median line, about three eighths of the length of the body from the anterior end. It is $0.147 \mathrm{~mm}$ by $0.117 \mathrm{~mm}$ in the smaller specimena anc 0.176 by $0.147 \mathrm{~mm}$ in the largest ones. The long axis is parallel to that of the body. The oviduct arises from the median, dorsal, posterior part of the ovary and soon expanas into the fertilization space. Then on turning ventrad, it receives the common vitelline duct, and this entire region is surrounded by the large secretive cells of the shell glond. After receiving the efferent ducts of the shell gland, Laurer's canal is given off. It turns posteriad and dorsad, opening to the surface $0.15 \mathrm{~mm}$ caudad of the ovary. This canal is $0.004 \mathrm{~mm}$ in diameter and was empty in the sectioned worms.

The uterus is a much coiled tube extending caudad as far as the anterior testis, where it turns cephalad and continues as a convoluted tube to the genital pore. In most of the specimens, it extends caudad on the left siàe of the body, returning on the right side. In several specimens however, after extending about one third of the distance to the testis, it crosses to the opposite side of the body, passing posteriorly on the right side, and after returning on the left side to the point of crossing winds anteriorIy on the right sice of the boiy to the common genital pore. The uterus lies almost entirely between the intestinal caeca, but in specimens that are very much congested with eggs, the coils of the uterus may overly the intestine half the distance from the ovary to the anterior testis on one or both sides.

The vitellaria are arranged in nine lobes on the right, and twelve lobes on the left sice of the body, laterad of the 

intestinal caeca. Often the separate lobes are not distinct, but are massed together and overlap. Anteriorly they extend about one third of the distance from the ovary to the acetabulum, terminjust cephalad of the posterior end of the cirrus sac, and posteriorly they extend about five sixths of the distance from the ovary to the anterior testis. There are 20 to 40 follicles in each lobe, and in stained material, the nuclei of the cells are conspicuous among the yellow vitelline globules.

The genital pore (Fig.28) is on the ventral surface, just anterior to, and slightly left of the acetabulum. The opening of the uterus is anterior and slightly at the left of that of the cirrus sac.

The efgs occur in enormous numbers, filling the uterus. They average 0.031 by $0.015 \mathrm{~mm}$ in size, but those near the ovary are more spherical, being 0.031 by $0.019 \mathrm{~mm}$. In most of the ergs the reagents had caused the shell to collapse, and in many cases the cap had come off. The contents were granular in appearance. There are two testes; They lie one bohind the other at the nosterior part of the body, altho in some cases they are slightly on opposite sices of the median line. They are close together being only only 0.05 to $0.1 \mathrm{~mm}$ apart, but did not overlap in any case. The testes are about the same size and vary from 0.2 to $0.29 \mathrm{~mm}$ in length by 0.16 to $0.24 \mathrm{~mm}$ in width. In one immature worm there were three testes (Fig.25), the posterior one being of normal size anc in the usual position, while there vere two anterior testes, slightly smaller than normal, one on either side of the median line. 

The duct from the anterior testes arises at the anterior ventral margin and runs cephalad ventrad of the caecum of the left side. The duct from the posterior testes arises at the anterior lateral margin and passes cephalad ventrad of the caecum of the right side. The sperm ducts pass cephalad on the median sides of the diverticula, becoming more median and dorsal as they pass forward; at the region of the ovary they cross dorsal to the excretory tubes and then pass on the median side of these tubes to the posterior end of the cirrus sac, where they unite to form the seminal vesicle. The cirrus sac (Fig.26) is 1.18 to $1.295 \mathrm{~mm}$ in length and $0.088 \mathrm{~mm}$ wide at the widest part. It extends caudad from the genital pore about three fourths of the distance to the ovary. The two sperm ducts unite at the posterior end and form a large, dilated seminal vesicle which lies entirely within the cirrus sac. This seminal vesicle stains heavily, due to the masses of spermatozoa it contains, Anteriorly the tube is reduced in diameter and passes thru the region of the prostate gland, being surrounded by the large cells of that organ. Then after a much coiled portion it passes as a straight tube to the pore

The posterior tip of the body is often slightly invaginated, the excretory pore being situated at the base of this shallow invagination. There is a single large median collecting duct, which extends cephalad to the region of the ovary where it divides into two branches, extending one on either side to the region of the genital pore. From these, smaller branches were traced anteriorly but the smaller ducts of the excretory system were not followed. 

In the material of this species there were many immature forms. The smallest mounted (Fig.23) is $0.65 \mathrm{~mm}$ in length and $0.16 \mathrm{~mm}$ in width, the younger worms are wider proportionately than the adults. In this specimen the oral sucker is $0.025 \mathrm{~mm}$ in diameter and is followed by an esophagus of equal length, the esophagus being more prominent and distinct than in the adult. The caeca of the intestine extend to the posterior end of the body. The excretory system is well aeveloped and similar to that of the adult. The acetabulum is very small, $0.03 \mathrm{~mm}$ in diameter, and the anlage of the cirrus sac and those of the ovary and testes are merely masses of heavily staining cells, those which are to form the testes not yet having become separated into two parts.

In a larger specimen (Fig.27) $1.7 \mathrm{~mm}$ long, the body has become more elongate. It is $0.2 \mathrm{~mm}$ wide at the widest part. The suckers have increased in size, the oral to $0.09 \mathrm{~mm}$ and the acetabulum to $0.63 \mathrm{~mm}$ in ciameter. Simultaneous with these changes, the anterior part of the intestine has taken on the characteristic shape of the adult. The ovary has assumed cefinite shape, the testes have now become separates as two circular structures and the cirrus sac is well defined at the anterior end al tho the posterior end is extended as line of deeply staining cells, reaching to and apparentlyconnected with the ovary. Ho traces of uterus or vitellaria could be distinguished. 

A brief specific diagnosis of $\mathrm{T}$.corti.

Size: 4 to $7 \mathrm{~mm}$ long, greatest width $0.5 \mathrm{~mm}$.

Shape; elongate, flattened dorsoventrally.

Cuticula; spined.

Oral sucker; sub-terminal, $0.14 \mathrm{~mm}$ in diameter.

Acetabulum; one sixth to one seventh of length from anterior end. Esophagus; present.

Ovarg: $0.15 \mathrm{~mm}$ in diameter, three eighths of length from anterior end.

Laurer's canal; present.

Uterus; coils usually between caeca, crossing in some cases.

Cirrus sac; extends $\frac{3}{5}$ of distance from acetabumum to ovary.

Vitellaria; 9 lobes on the right, 12 on the left side of body.

Genital pore; anterior and left of the acetabulum.

Legs; numerous, $0.031 \mathrm{~mm}$ by $0.015 \mathrm{~mm}$.

Stossich (1904), Goldberger (1911), and Barker and Covey

(1911) have comiled careful and detailed keys for the identification of the species of the genus Telorchis. Their work is so complete that further comparisons in this paper are unnecessary.

T.corti agrees closely only with $\mathrm{T}$.aculeatus von Linstow and T.solivagus odhner, the nearest resemblance being with $\mathrm{T}$. aculeatus. However it can not be assigned to either of these species because of certain specific differences.

A comparison of the species can best be made in a tabulated form. 



\begin{tabular}{|c|c|c|c|}
\hline Characters & T.aculeatus & T.solivagus & T.corti \\
\hline Length & 5 to $7 \mathrm{~mm}$ & 4 to $7 \mathrm{~mm}$ & 1 to $7 \mathrm{~mm}$. \\
\hline Width & $1 \mathrm{~mm}$ & 0.8 to $0.9 \mathrm{~mm}$ & 0.4 to $0.5 \mathrm{~mm}$. \\
\hline Oral sucker & 0.16 to $0.24 \mathrm{~mm}$ & 0.19 to $0.24 \mathrm{~mm}$ & 0. $14 \mathrm{~mm}$ in dia. \\
\hline Acetabulum & 0.14 to $0.18 \mathrm{~mm}$ & $0.28 \mathrm{~mm}$ & $0.14 \mathrm{~mm} " \quad "$. \\
\hline Pharynx & $0.11 \mathrm{~mm}$ & $0.146 \mathrm{~mm}$ & 0.7 to $0.8 \mathrm{~mm} " 1$. \\
\hline Esophagus & $0.13-17 \mathrm{~mm}$ & $0.35 \mathrm{~mm}$ & $0.5 \mathrm{~mm}$ long. \\
\hline Ovary & $\begin{array}{l}0.17 \mathrm{~mm} \text { in dia. } \\
\text { at posterior } \\
\text { end of cirrus } \\
\text { in median line }\end{array}$ & $\begin{array}{l}0.27 \mathrm{~mm} \text { in dia. } \\
\text { under posterior } \\
\text { end of cirrus } \\
\text { left of median }\end{array}$ & $\begin{array}{l}0.15 \mathrm{~mm} \text { in dia. } \\
0.3 \mathrm{~mm} \text { behind post } \\
\text { end of cirrus. } \\
\text { left of median. }\end{array}$ \\
\hline Laurer's canal & $?$ & $?$ & present. \\
\hline Uterus & $\begin{array}{l}\text { right limb descer } \\
\text { ding, left limb } \\
\text { ascenoing. }\end{array}$ & en crosses & crosses \\
\hline Testes & $\begin{array}{l}0.27-0.36 \mathrm{~mm} \\
\text { separated }\end{array}$ & $\begin{array}{l}0.5-0.42 \mathrm{~mm} \\
\text { contiguous }\end{array}$ & $\begin{array}{l}0.2-0.25 \mathrm{~mm} \\
\text { separated }\end{array}$ \\
\hline Cirrus sac & reaches to ovary/ & $\begin{array}{l}\text { T/extenàs posteri } \\
\text { to ovary }\end{array}$ & $\begin{array}{ll}\text { or/extends } & 3 \text { of } \\
\text { length to ovary }\end{array}$ \\
\hline Genital pore & $\begin{array}{l}\text { anterior to } \\
\text { acetabulum }\end{array}$ & $\begin{array}{l}\text { anterior to } \\
\text { acetabulum }\end{array}$ & $\begin{array}{l}\text { anterior and left } \\
\text { of acetabulum. }\end{array}$ \\
\hline Vitellaria & $\begin{array}{l}8-9 \text { on right } \\
12-13 \text { on left }\end{array}$ & $\begin{array}{l}\text { indefinately } \\
\text { arraneed }\end{array}$ & $\begin{array}{l}9 \text { on right side } \\
12 \text { on left side. }\end{array}$ \\
\hline Eggs & $0.046-0.019 \mathrm{~mm}$ & $0.03-0.015 \mathrm{~mm}$ & $0.031-0.015$ \\
\hline Host & $\begin{array}{l}\text { Testudo graeca } \\
\text { Europe }\end{array}$ & $\begin{array}{l}\text { Llemmys caspia } \\
\text { Lurope }\end{array}$ & $\begin{array}{l}\text { I. Ieseurii } \\
\text { IN. A. }\end{array}$ \\
\hline
\end{tabular}

The forms are about the same length, T.corti being

narrower and thicker than the others; the oral sucker and pharynx are smaller in T.corti and the esophagus is shorter. The crossing or absence of crossing of the uterus has been used as a specific character, but both conditions are found in Tocorti. The structure of the ootype is unknown in T.aculeatus and m.solivagus. The cirrus sac is shorter in T.corti, extending only three fourths 

of the distonce from the genital pore to the ovary, while in the other forms it reaches to the ovary. The arrangement of the vitellaria is similar to that in T.aculeatus but different from $T$. solivagus. The eggs of T.corti are about the same size as those of solivagus, but are smaller than those of T.aculeatus.

$$
\text { Classification. In 1899, Luehe and Looss, working }
$$

independently, each created a new genus, Telorchis, to contain a certain group of distomes from reptiles, which seemed to have common characters, so constant and unique as to warrant their separation into a new genus.

Luehe took Distoma clava as a type, and included the species, poirieri (gelatinosum), Iinstowi (aculeatus), ercolanii ( nematoides), bifurcus and pleriticum. As generic characters he gave," Testes median, one behind the other, at the posterior end of the body, cirrus sac very long, opens anteriorly and at the left of the acetabulum. Ovary immeaiately behind the cirrus sac, uterus coils in the body anterior to the testes, vitellaria of many follicles occupy sides of the body, caeca extend to the posterior end of body; with the exception of T.poirieri, body is spined; excretory bladder long, branching anteriorly; oral sucker larger than acetabulum in ercolanii, usually about equal size".

Looss took D. Iinstowi ( aculeatus) as a type, and included the species poirier, nematoides and arrectum. As generic characters he designates the following," Boày long, smaller anteriorly; spines present or absent; short esophagus, diverticula extending to the posterior end of the body; genital opening anterior to the acetabulum; cirrus present, long, extending far posteriorly; testes behind one another, at the posterior end of the body; 

ovary far distant, somewhat lateral, lying in the region at the end of the cirrus sac; Laurer' $s$ canal present."

Because of the difference of T.clava from the other members of his genus Telorchis, Luehe (1900) divided the genus into two sub-genera, Telorchis, with T.clava as a type, and Cercorchis, with T.linstowi as a type. To the sub-genus Telorchis he ascribes those forms with no esophagusand with uterine coils not confined between the caeca, while to Cercorchis the forms with an esophagus and with the coils of the uterus confined between the intestinal diverticula. Regarding these identifying characters, he says the presence or absence of an esophagus is of major importance.

Looss (1902) characterized Iuehe's genus Telorchis as an unnatural group, but fails to find adequate ground to justify the division into tiro sub-genera. Luehe certainly was unfortunate in the selection of identifying characters for his sub-genera, for an intracaecal coiling of the uterus is not necessarily associated with the presence of an esophasus, since in $T \cdot p l e r o t i c u s$ and T.bifurcus the coils of the uterus are confined between thenand the esophagus is absent. In his separation into sub-genera Iuehe's sub-genus Cercorchis corresponds identically with Looss genus Telorchis, except that Looss did not make the error of associating the presence or absence of an esophagus, which itself is a variable condition, with an indefinite character like the extent of the coiling of the uterus. The extent of coiling depends to a large extent on the fecundity of the worm; in T.corti, in which the uterine coils are usually contained within the aiverticula, in specimens that are very much congested with eggs, the coils of the uterus overly the intestine. 

Luehe's description of Telorchis was published in the Eool. Anz. of Dec.28, 1899, and Looss' account was printed in the Eool. Jahrb. of the same date. llost workers have credited the genus to Iuehe, altho odhner(1902) in his description of T.solivagus ascribes the genus Telorchis to Looss.

As regarois the t:vo sub-genera of Iuehe, since the extent of the coiling of the uterus is not associated with the presence or absence of an esophagus, the coiling of the uterus must be abandoned as a diagnosing character, and the only difference between the sub-genera becomes that of the presence or absence of an esophagus. Such a variable and uncertain character as the presence or absence of an esophagus certainly does not warrant the separation of a genus into two sub-genera. 

Bibliography.

Barker, F.D. and Covey, G.W. 1911. A New Species of Trematode

from the Painted Terrapin, Chrysemys marginata.

Nebraska Univ. Stud.,11:472-961;3pl.

Braun, I. 1890. Plathelminthes ilinot 1877. In Bronn, H.G. Klassen und Ordnungen der Thier-Reichs. vol.4,pt.1, 1,:303-925;28pl.

....... 1901. Trematoden der Chelonier. Mitt. Zool. Mus. Berlin, 2:13-20; Ipl.

Goldberger, J. 1911. On Some New Parasitic Trematode Worms of the Genus Telorchis. Bull. No.7l, Hyg. Lab., T.S. Pub. Eealth \& liar.-Hosp. Serv., Tash. :36-48.

Jygerskiold, I.A. 1899. Ueber den Bau von Macraspis elegans. Öfvers. Vet. Akad. Fordh., 3:197-214;1pl.

Kofoid, C.A. 1899. The Identity of Cotylaspis insignis Leidy and Platyaspis anadontae Osborn, Zool. Bull-,5:179-185.

Leidy, J. 1857. Observations on the intozoa found in Naids.

Proc. Acad. Nat. Sci.,Phila,, 1857:18.

........ 1858. Contributions to Helminthology. Proc. Acad.

Nat. Sci. Phila., 1858:110.

-...-... 1888. Entozod of the Terrapin. Proc. Acad. Nat. Sci.

Phila., 1888:127.

Looss, A. 1899. Weitere Beiträge zur Kenntniss der Trematoden

Fauna Aegjptens. Zool. Jahrb., 12:521-784; 6pl.

1902. Uober Neue una Bekannte Trematoden aus Schildkroten. Zool. Jarb., Syst., 16:411-794.

Luehe, 1: 1899. Zur Kenntnis einiger Distomen. Zool. Anz•, $22: 524-539$. 

sen.. Centr. Bakt., 1 Abt.,28:524-539.

Monticelli, S. 1892. Cotylogaster michaelis. Fest. Leukart:

$$
166-214 ; 2 \mathrm{pl} \text {. }
$$

Nickerson, W.S. 1902. Cotylogaster occidentalis n.sp. and a Revision of the family Aspidobothridae. Zool. Jahrb.,5:597-624;2pl. Odhner, Th. 1898. Ueber die geschlechtsreife Form von Stichocotyle. Z001. Anz.,21:509-513.

Osborn, H.I. 1904. On the Habits and Structure of Cotylaspis insignis Leidy. Z001. Jahrb.,21:200-240;3pl.

Poirier, J. 1886. Trematodes Nouveaux ou peu Connus. Bull. Soc. Phil. Paris, 5:10;1pl.

Stafford, J. 1896. Structure of Aspidogaster conchicola. Zool. Jahrb., 9:477-537;4pl.

Stossich, M. 1895. I distomi dei rettili. Boll. Soc. Adriat. di sc. nat. in Trieste, 16:213-293;2pl.

1904. Alcuni distomi della collezione elmintologica del museo zoologico di NapoLi. Irus.z0ol. Univ. Napoli,1:1-10. Taschenberg, $\mathbf{E} \cdot 0$. 1879. Zur Systematik der Fonogenetischen Trematoden. zeit. gesammt. Naturwissensch.,52:232-265. Willemoes Suhm, R. 1872. Zur Naturgeschichte des Polystoma integerrimum and des P.ocellatum Fud. Leit. wiss. Zool-,22:29-39. Wright, R.R. 1879. Contributions to American HelminthologJ.

Proc.Canad. Inst., $1: 12-13$.

Zeller, E. 1872. Untersuchen ueber die intwicklung und den Bau des Polystomum integerrimum Rud. Zeit, wiss. Z0o1.,22:1-28. 1876. Weiterer Beitrag zur Kenntniss der Polystomen. Zeit. wiss. Z001.,27:238-275. 

Abbreviations used in Plates.

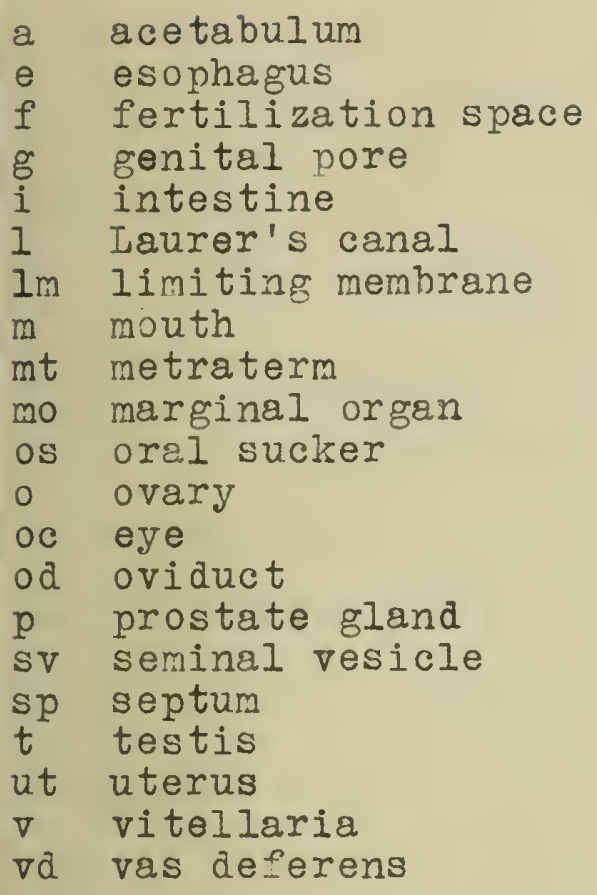

\section{Explanation of Plates. Plate I}

Fig.1. Cotylaspis rhadina somewhat extended, dorsal view.x40.

Fig.2. Cotylaspis rhadina, ventral view, showing the position of the marginal organs and the divisions of the adhesive disc. $x 40$.

Fig.3. Contractea specimen of C. rhadina, dorsal view. $\mathbf{x} 40$.

Fig.4. Diagrammatic representation of the excretory system in C. rhacina, dorsis view. x 40 .

Fig.5. Cross section thru the region of the ovary of c. rhadina, showing a section of an ego in the uterus. $x 85$.

Fig. 6. Frontal section thru the adhesive disc of C. rhadina, showing the musculature. $\times 95$.

Fig.7. Reconstruction of the reproductive organs of C. rhadina, from frontal sections - x 80 . 



\section{Plate II}

Fig.8. Sagittal section thru the anterior end of C. rhadina, showing musculature, digestive, reproductive, and marginal organs. The section is at the right of the median line. $\mathrm{x} 200$.

Fit.9. Sagittal section thru the dorsal body wall, showing the cuticula, the muscle la ers, a section of body parenchma, and the wall of the aigestive tube. x 550 .

Fig.10. Frontal section thru the mouth funnel of c. rhadina, showing the absence of an oral sucker. $x 300$.

Fig.ll. Frontal section thru the genital pore, showing the relations of the cirrus sac ana metraterm. $x 180$.

\section{Pla.te III}

Fig.12. Polystoma orbiculare, ventral view. x 20.

Fig.13. Frontal section thru the dorsal commissure, showing the large ganglion cells, $x 60$.

Fig.14. Frontal section thru the pharynx and mouth funnel. The esophageal nerve ring and anterior vitellaria are shom. $x 60$.

Fig.15. Cross section P.orbiculare, at the region of the genital pore. $x 60$.

Fig.16. Cross section thru the testes. $x 60$.

Fig.17. Cross section thru the anterior bothria. $x 60$.

Fig.18. Hook from the genital coronet. x 550 .

Fig.19. Hook from the base of a bothrium. $x 550$.

Fig.20. Reconstruction of the reproductive organs of $P$. orbiculare, ventral vie. from frontal sections $x 40$.

Fig.21. Polystoma hassali, ventral view. $\times 40$. 



\section{Plate IV}

Fig.22. Telorchis corti, reconctruction of the female organs at the region of the ovary, from sagittal sections. $x 120$.

Fig.23. Immature worm, $0.65 \mathrm{~mm}$ long. $x 100$.

Fig.24. Telorchis corti, ventral view. $x 15$.

Fig.25. Abnormal specimen, three testes. $x 65$.

Fig.26. Cirrus sac. x. 45 .

Fig.27. Immature worm, $1.7 \mathrm{~mm}$ long. $x 45$.

Fig.28. Cross section thru the genital pore. $x 100$.

Fig.29. Cross section thru the posterior part of the ovary, showing the shell gland, the anterior part of the uterus on the right and the coils returning on the left, the excretory tubes are median and the digestive caeca are at the sides of the body. 


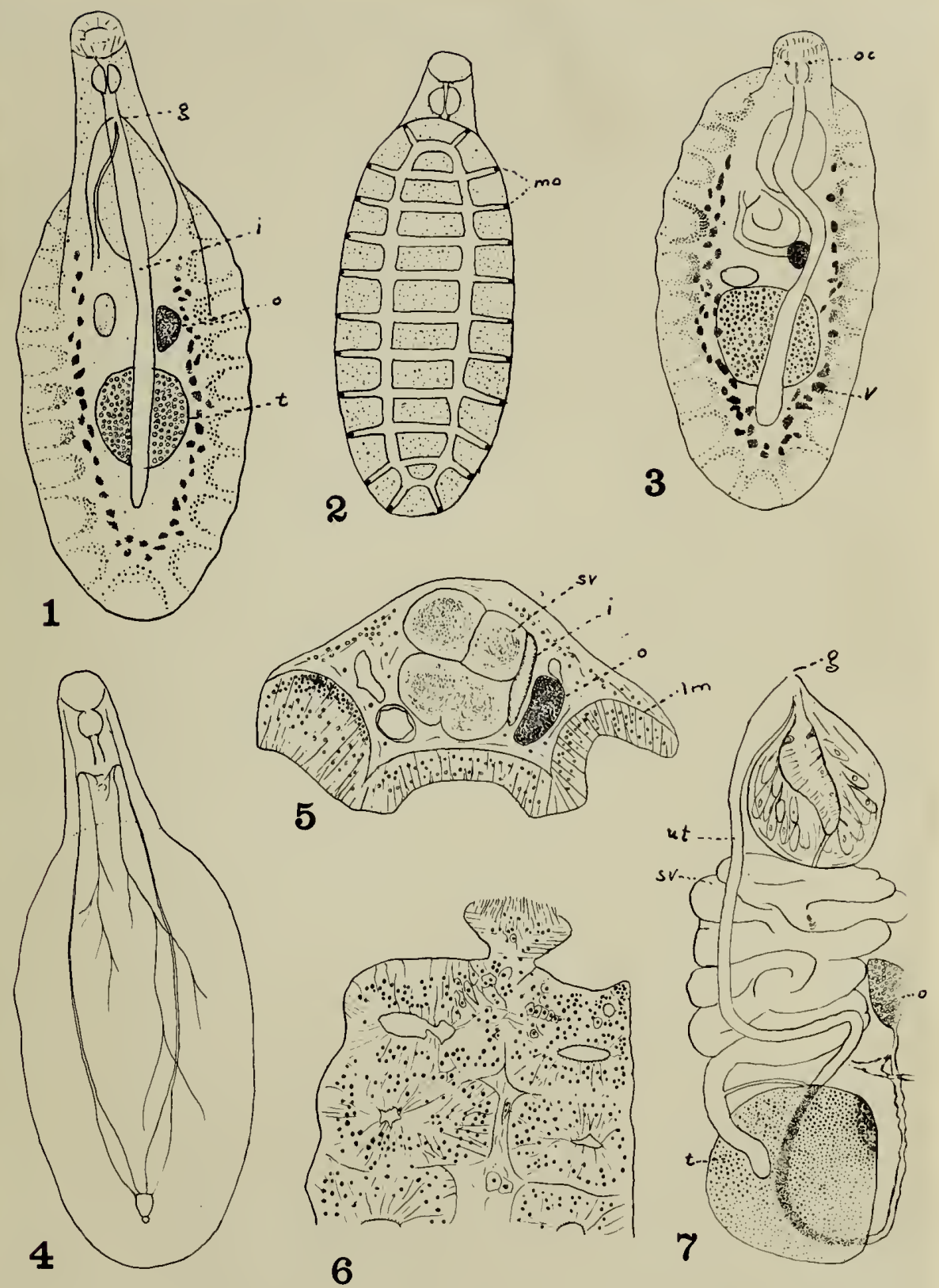


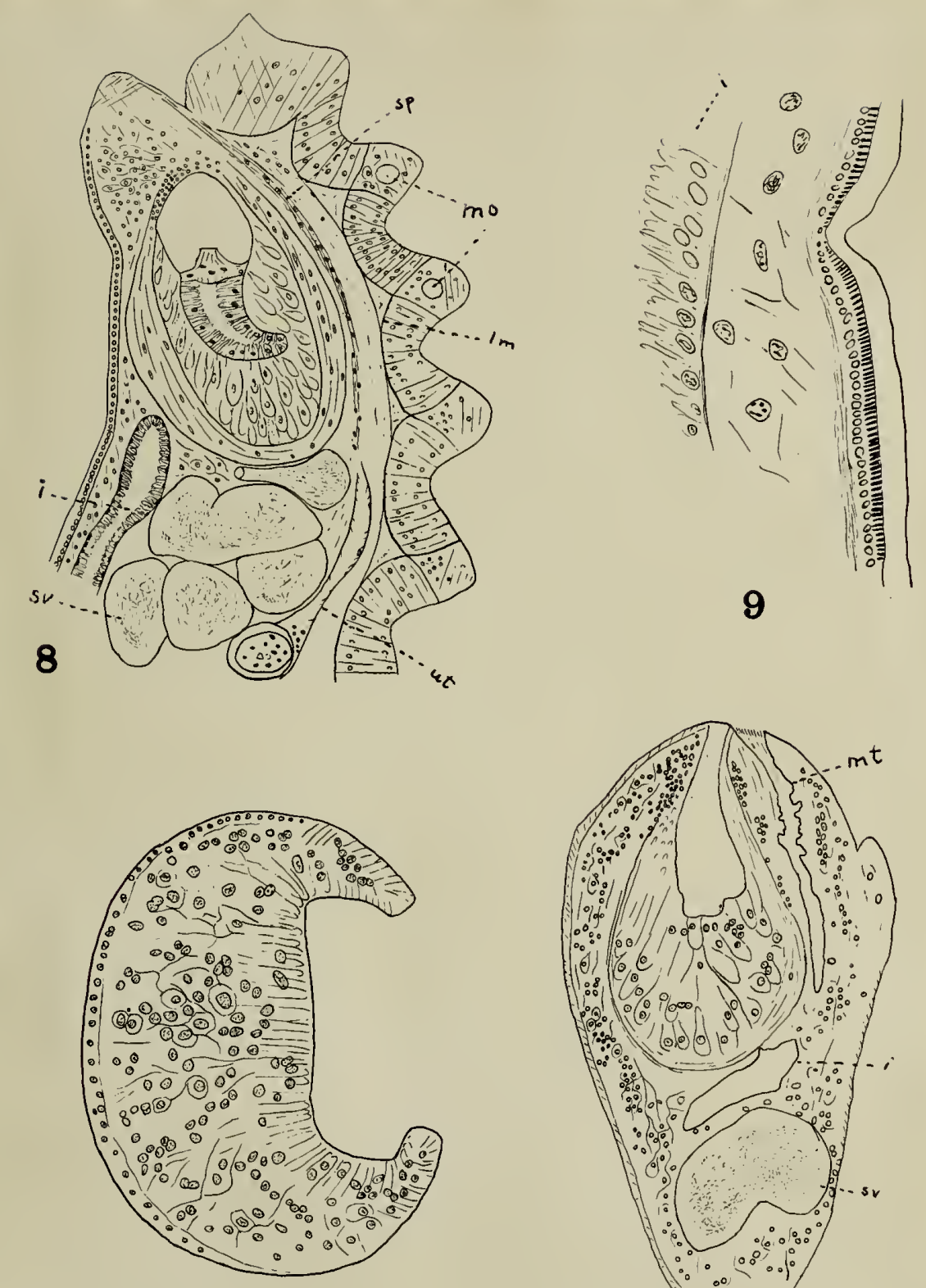

10

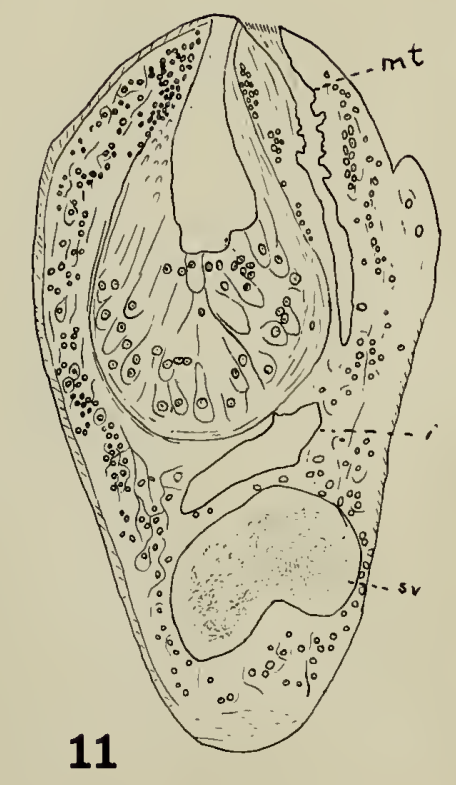



Plate III
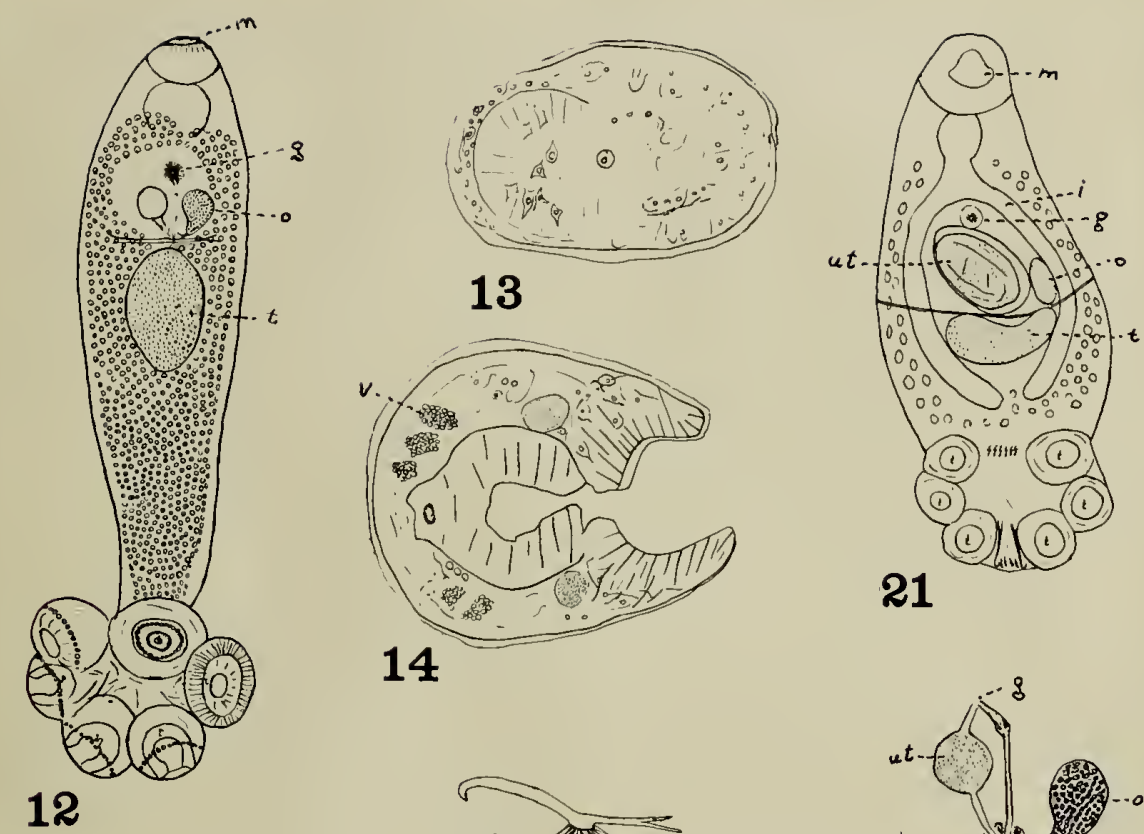

21

\section{4}

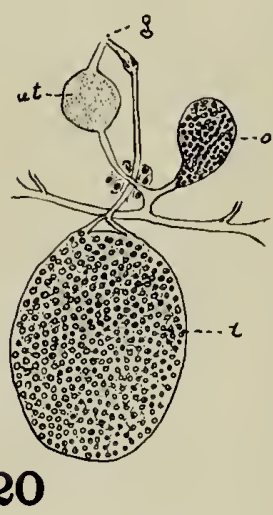

\section{5}

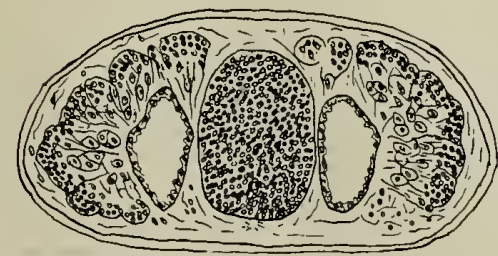

16
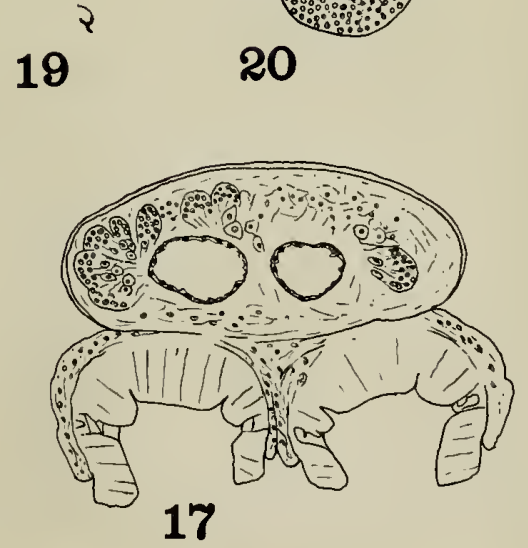


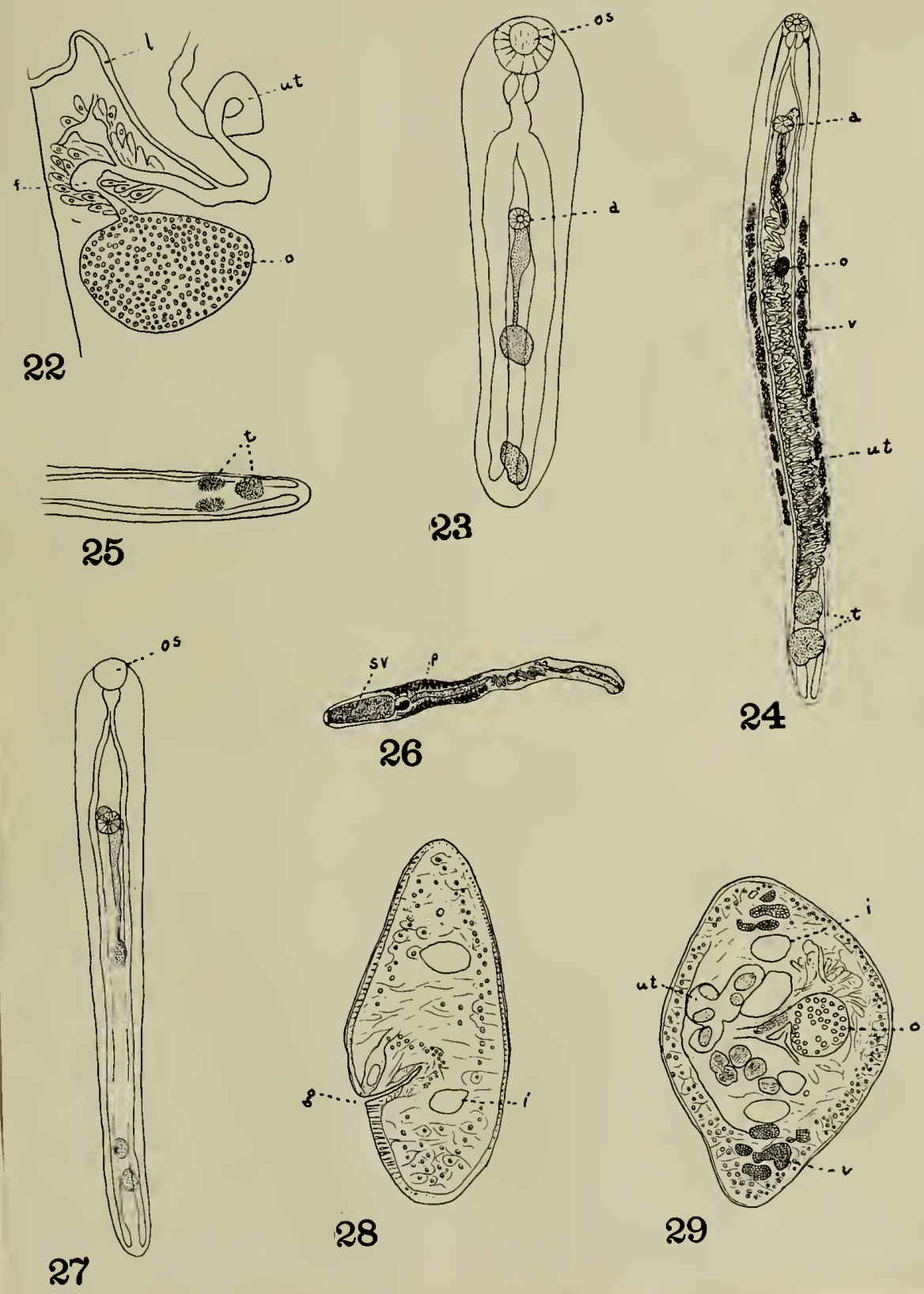


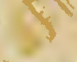

$$
24
$$
$3-2 ; 0$

$\frac{2}{2}$

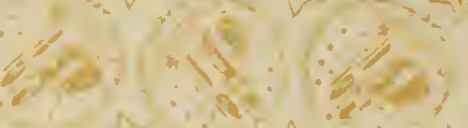

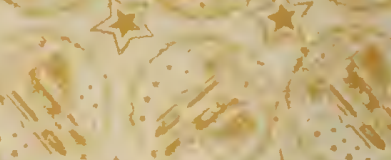
$\sum_{v} x^{2}=28$ $\because \because \because \frac{1}{2}$ \{

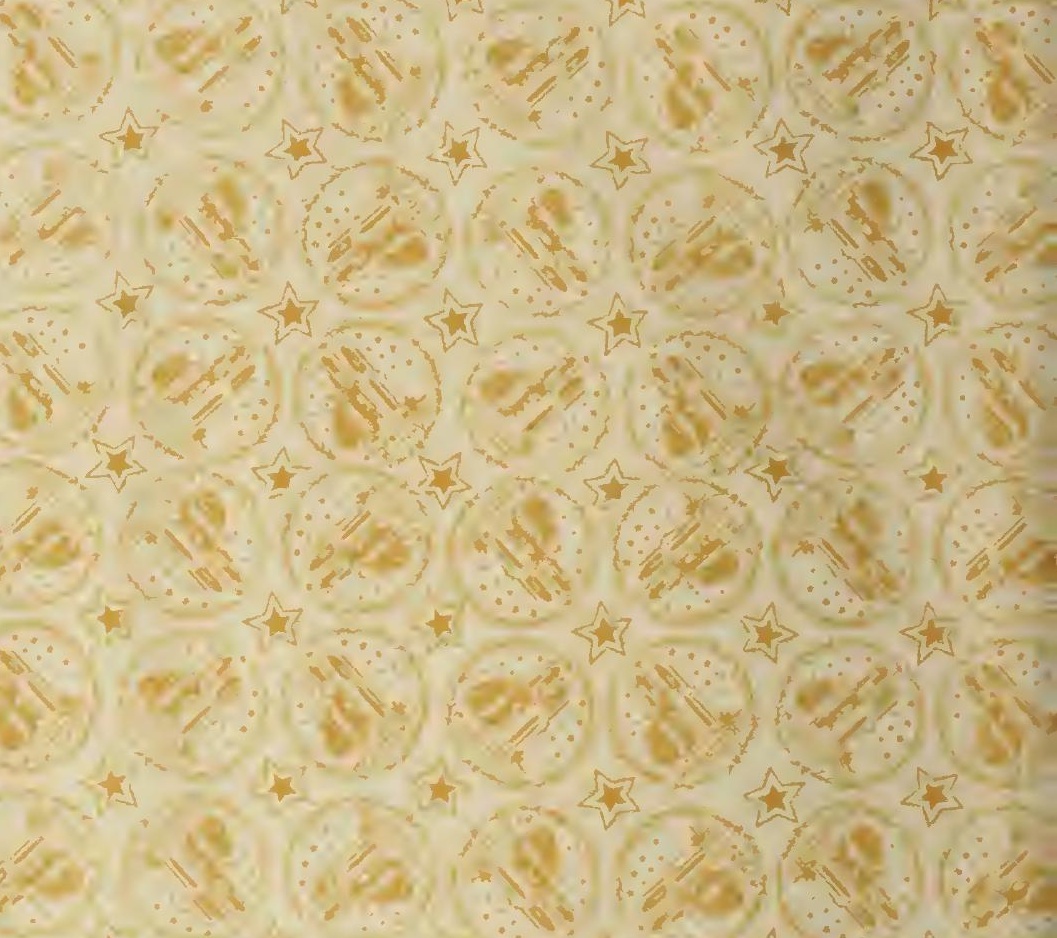
A
Q
s. $^{*}$

i.

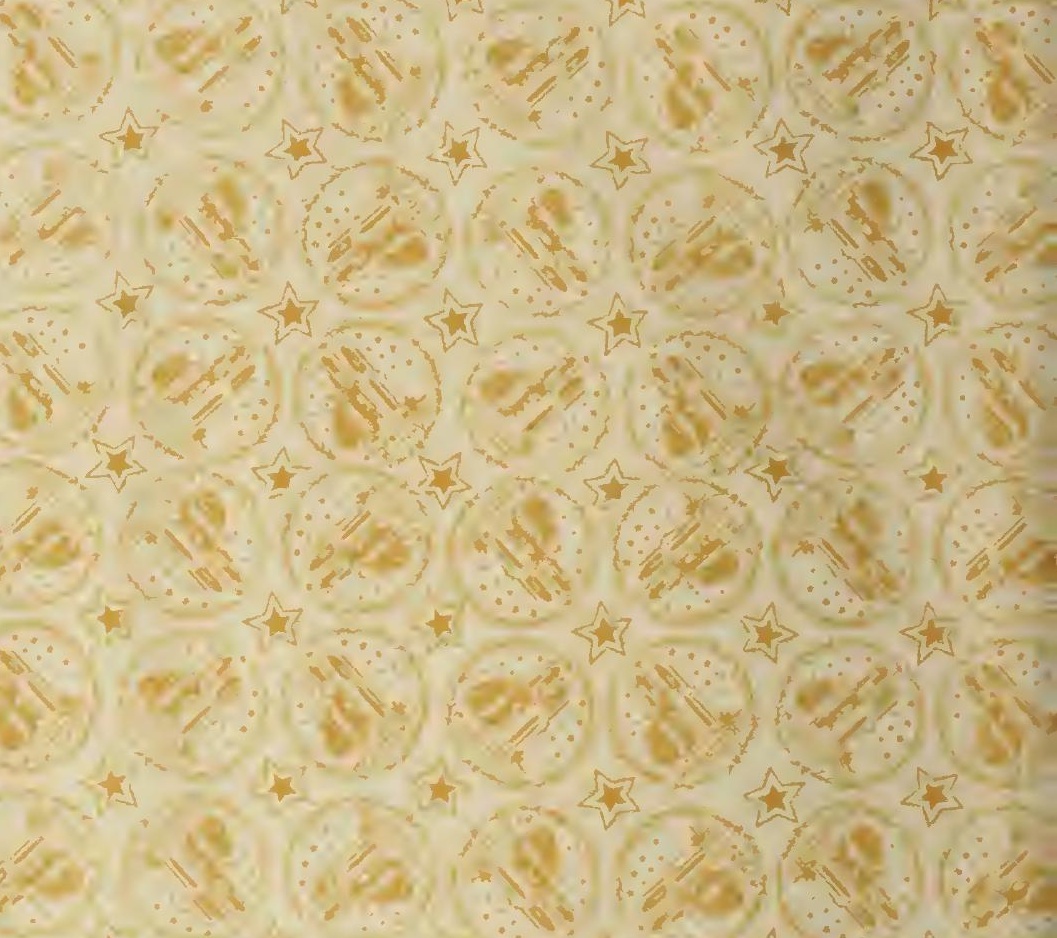

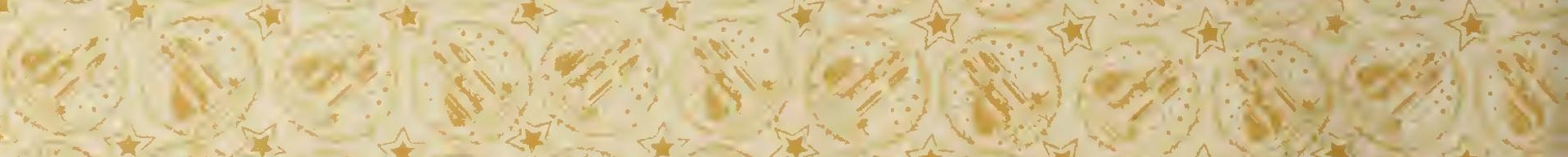

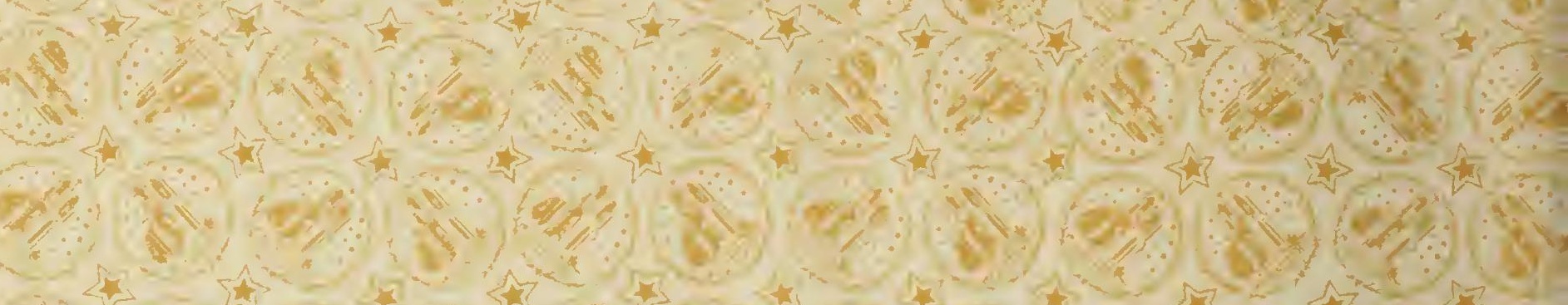

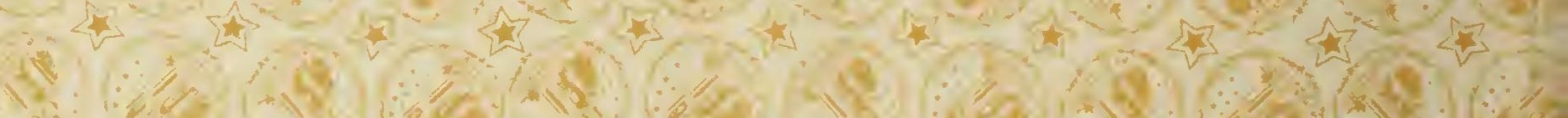
(5)

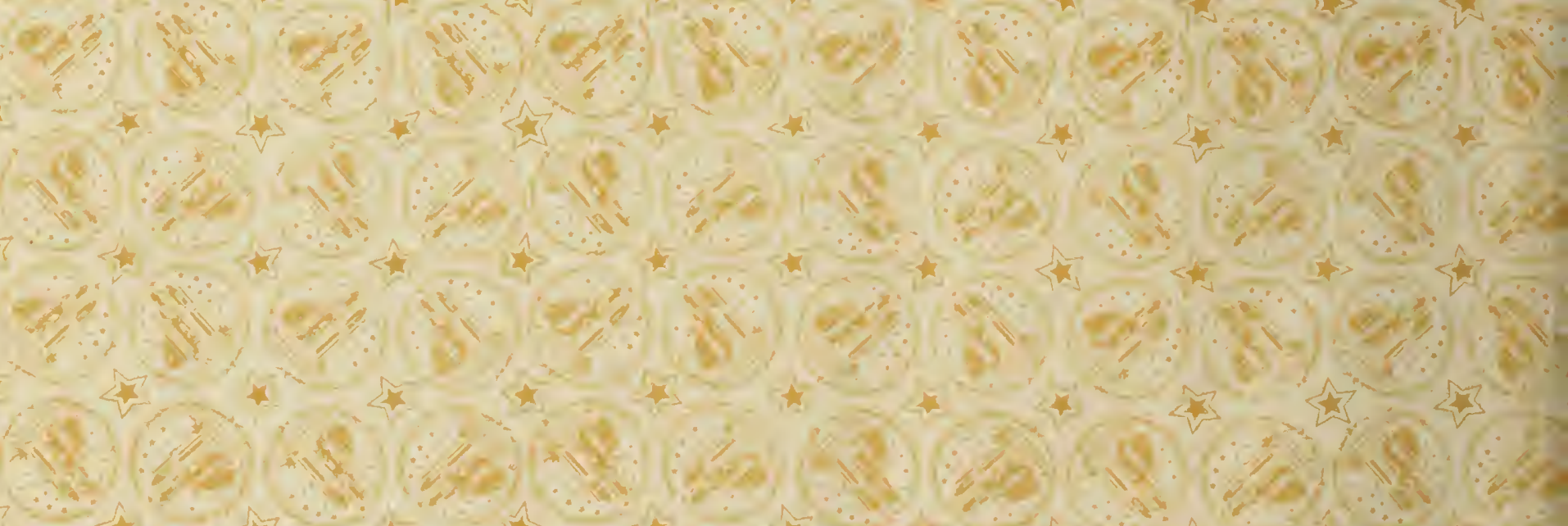

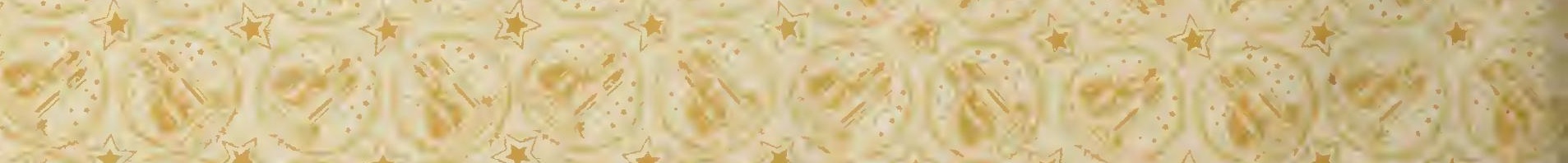

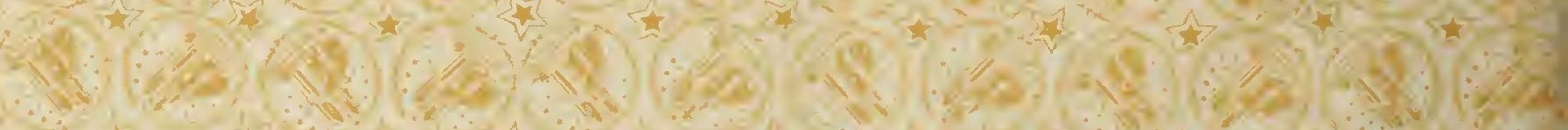

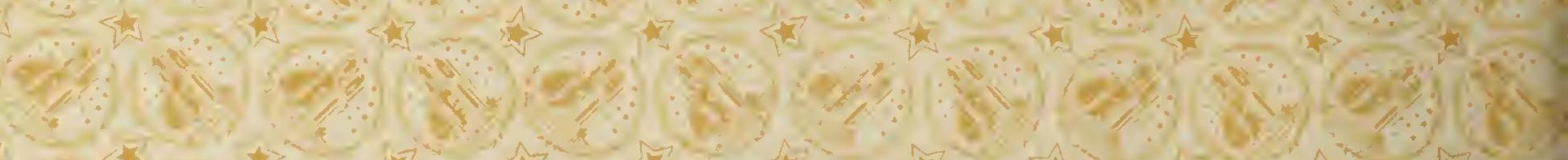

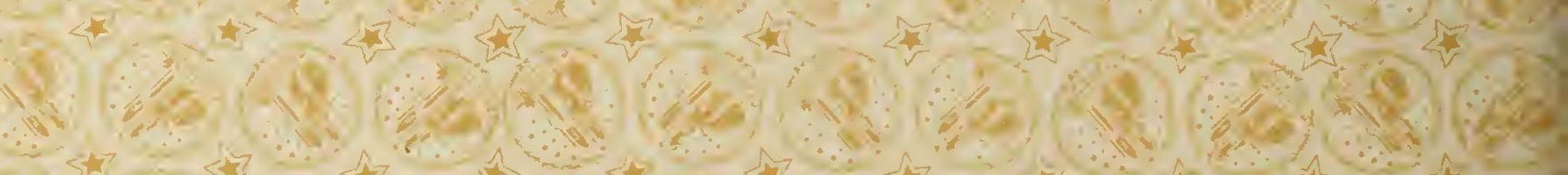

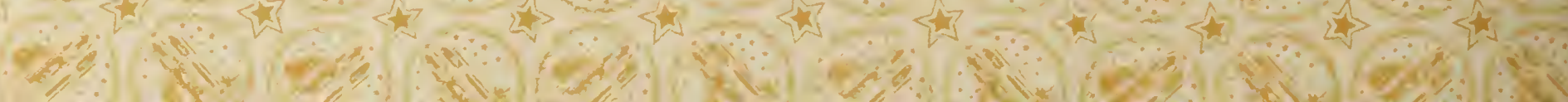




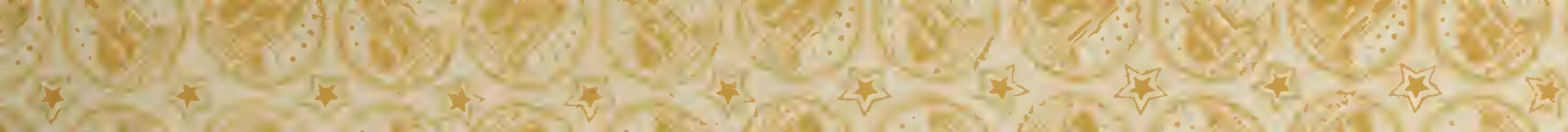

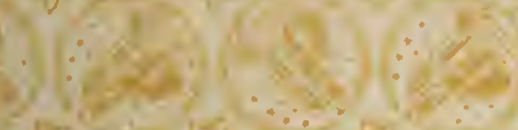
4

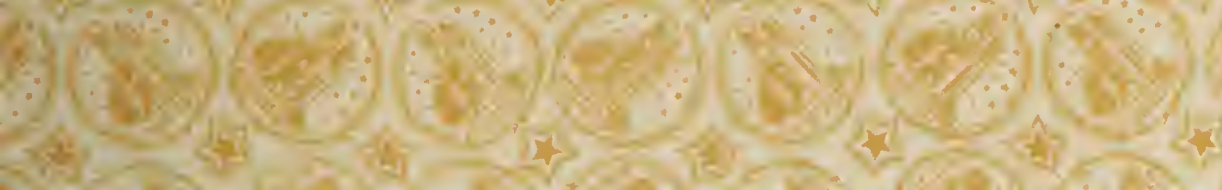

: $: 30$

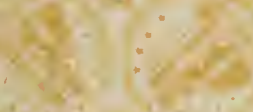

Y. $4 x^{2}=$

(6) 3 ?

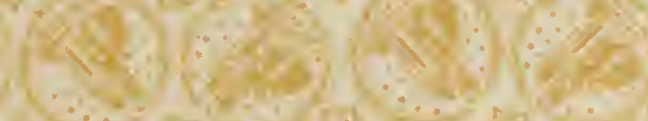

$4+\ldots 14$

$\therefore i_{i=1}^{\infty}$

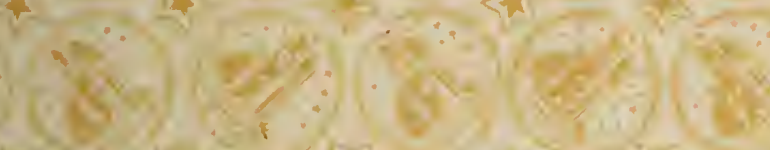

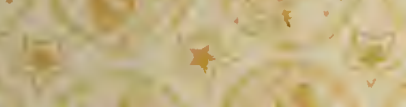

in $(x, 2)$

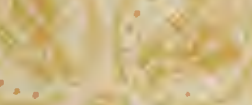

is) $>\frac{1}{1}$

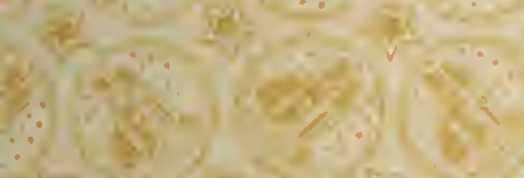

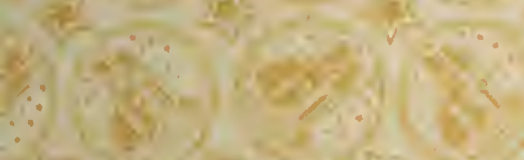

$-\frac{5}{5}$

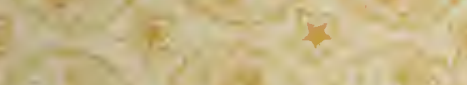

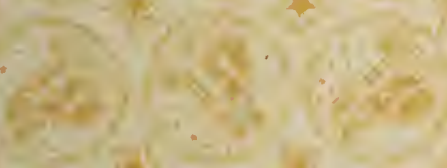

3.

72

4

isis

asing

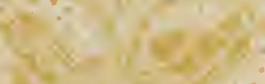

th.

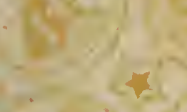

iside

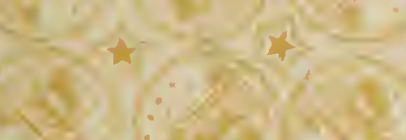

F

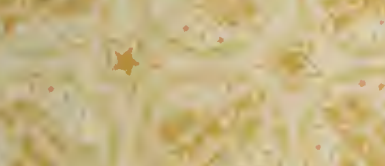

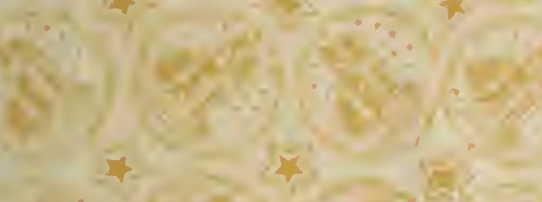

a

t.

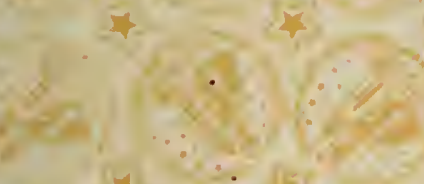

5.

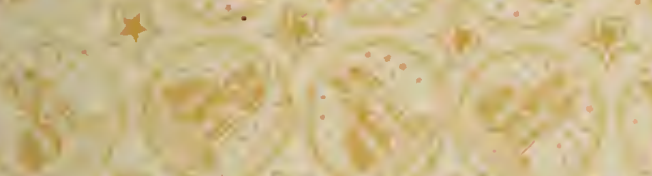

$7=2$

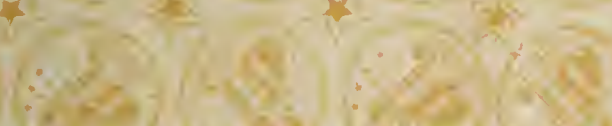

$\operatorname{los}^{2}=2$

$14{ }^{2} \because 48$

$\because$

(3)

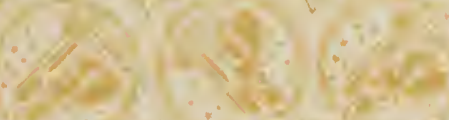

$(8 x+19 y$

$6 y$

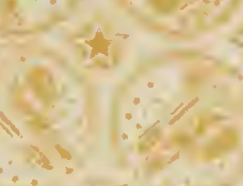

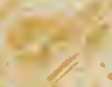

Q.) 3 :

8

$y^{2}$

120

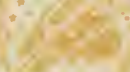

ist

$\therefore 6 x=$

$12+39.60$

$\therefore 8$

nosis. 
